\title{
Finno-Ugric Languages in Russian Education: the changing legal-institutional framework and falling access to native language learning
}

Les langues finno-ougriennes de Russie dans le système d'éducation: changement du cadre juridique et institutionnel et recul de l'accès à

l'apprentissage des langues maternelles

Konstantin Zamyatin

\section{(2) OpenEdition}

\section{Journals}

Electronic version

URL: https://journals.openedition.org/efo/821

DOI: $10.4000 /$ efo. 821

ISSN: 2275-1947

Publisher

INALCO

Printed version

Date of publication: 1 December 2012

ISBN: 978-2-343-02592-6

ISSN: 0071-2051

\section{Electronic reference}

Konstantin Zamyatin, "Finno-Ugric Languages in Russian Education: the changing legal-institutional framework and falling access to native language learning", Études finno-ougriennes [Online], 44 | 2012, Online since 12 February 2014, connection on 09 July 2021. URL: http://journals.openedition.org/efo/ 821 ; DOI: https://doi.org/10.4000/efo.821

This text was automatically generated on 9 July 2021.

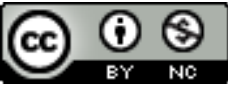

Études finno-ougriennes est mis à disposition selon les termes de la Licence Creative Commons Attribution - Pas d'Utilisation Commerciale 4.0 International. 


\title{
Finno-Ugric Languages in Russian Education: the changing legal- institutional framework and falling access to native language learning
}

\author{
Les langues finno-ougriennes de Russie dans le système d'éducation: \\ changement du cadre juridique et institutionnel et recul de l'accès à \\ l'apprentissage des langues maternelles
}

\author{
Konstantin Zamyatin
}

\section{EDITOR'S NOTE}

Konstantin ZAMYATIN, Department of Finnish, Finno-Ugrian and Scandinavian Studies, University of Helsinki, Finland. Email: konstantin.zamyatin@helsinki.fi. Research for this article was made possible through the grant of the Academy of Finland, research project Revitalization and Empowerment Trends among the EU and Russian Minorities (chair: Janne Saarikivi).

1 In the late Soviet period intergenerational language transmission among the FinnoUgric peoples of Russia was under decline in both family and school. That is why the national republics and other regions of post-Soviet Russia adopted extensions of native language teaching in school as one of the central goals of their language revival projects in an attempt to reverse the decline of non-Russian languages. Among the domains of language use in the public sphere, education is arguably the most important mechanism for ensuring the transmission of languages to the next generations (like the family in the private sphere). According to newly introduced democratic principles, private language use in the family was not a matter of regulations and restrictions, although compulsory use of languages in public sphere, including education, could and had to be introduced. To achieve this language extension goal, regional authorities 
adopted legislation and created further institutional frameworks for language education that introduced compulsory teaching of titular languages either to all students or only to those of titular nationality. Depending on the resulting configuration of the legal-institutional framework of language education, the dynamics in implementing the goal of language teaching extension varied in different regions.

2 So far, international research on linguistic politics in the Russian regions has mainly focused on the Turkic republics. In particular, Tatarstan's language education policy received intense attention from domestic and international scholars (Gorenburg 2005; Graney 1999 and others). The language education policy in the Finno-Ugric republics has received less scholarly attention: typically these domestic studies would be devoted to consideration of language situations in separate regions and the attempts to conduct any cross-regional comparisons were rare (for partial comparisons see: Lallukka 1994, Mosin 2010, Savelyeva 2000, Shutov 2003, Strogalshchikova 2008). Addressing this gap, a systemic comparison of the language education in the Finno-Ugric and Volga Turkic republics has been done that presented preliminary data on the extent of language teaching in an attempt to reveal the trends in the twenty-year post-Soviet dynamics (Zamyatin 2012b). However, to gain a deeper understanding not just of results, but also of possible causes for these trends, one should further connect the trends to the changes in the institutional position of languages in education according to regional legislations. Moreover, to address institutional variety, a study should undertake a comparison across dissimilar types of regions. How have different regional configurations of the legal-institutional framework affected language teaching?

The purpose of this study is to explore the institutional position of Uralic languages (Finno-Ugric and Samoyed, further-Finno-Ugric languages) in Russia's regional education systems in order to find out its effect on language teaching in different regions. The choice of specifically Finno-Ugric languages and regions was determined by the fact that the diverse situations of Finno-Ugric languages reflect the linguistic diversity of Russia as a whole. The languages belonging to this group are divided among the three major categories of minority languages spoken in Russia. Some of them have been declared 'state languages' of Russia's national republics; these are Komi (hereafter-KR), Mari El (RME), Mordovia (RM), and Udmurtia (UR); the titular language is not the state language of Karelia (KR). Others are classified as 'languages of small numbered indigenous peoples of the North'. Some of these indigenous languages have been assigned the status of 'official languages' in regional legislations of autonomous districts (the Nenets (NAD), the Yamal-Nenets (YNAD), and the Khanty-Mansi (KMAD) autonomous districts). Yet the others are 'languages of ethnic communities' in other (non-titular) regions (in the republics of Tatarstan (RT) and Bashkortostan (RB), in the Kirov, Leningrad, Murmansk, Nizhniy-Novgorod, Tver and some other regions, in Krasnoyarsk Territory and Perm Territory, etc.). This diversity is also represented in Russian education: according to official accounts out of seventy-five languages used in education, thirteen languages are Finno-Ugric (Pravovoi status 2011).

The approach of this study is to compare institutional settings of regional education systems in order to test the theory that the institutions were of crucial importance for developments in Russia's regions (see Gorenburg 2003). This comparison is possible because the teaching of Finno-Ugric languages in different types of regions (republics, autonomous districts, and 'ordinary' regions) is based on common principles and possibilities provided in the Russian education space, the inter-connectedness of 
federal and regional legislations. In its first section on the study methods, the article will elaborate on the process of comparison and will examine the legal and institutional framework of non-Russian language teaching built up in the Russian education system in the early 1990s. This framework predetermined possible ways of implementing the regional language revival policy and the methods and procedures of its evaluation. The study gives only a short overview of the general Russian framework for language education (for an extended analysis see Zamyatin 2012a) and is rather devoted to the regional developments. A separate interesting issue not discussed here is how and to what extent the nationalist elites were able, on the rise of popular movements, to push their nationalist agenda as part of language demands on regional authorities and forced them to make certain choices.

Status of the Finno-Ugric languages in Russia

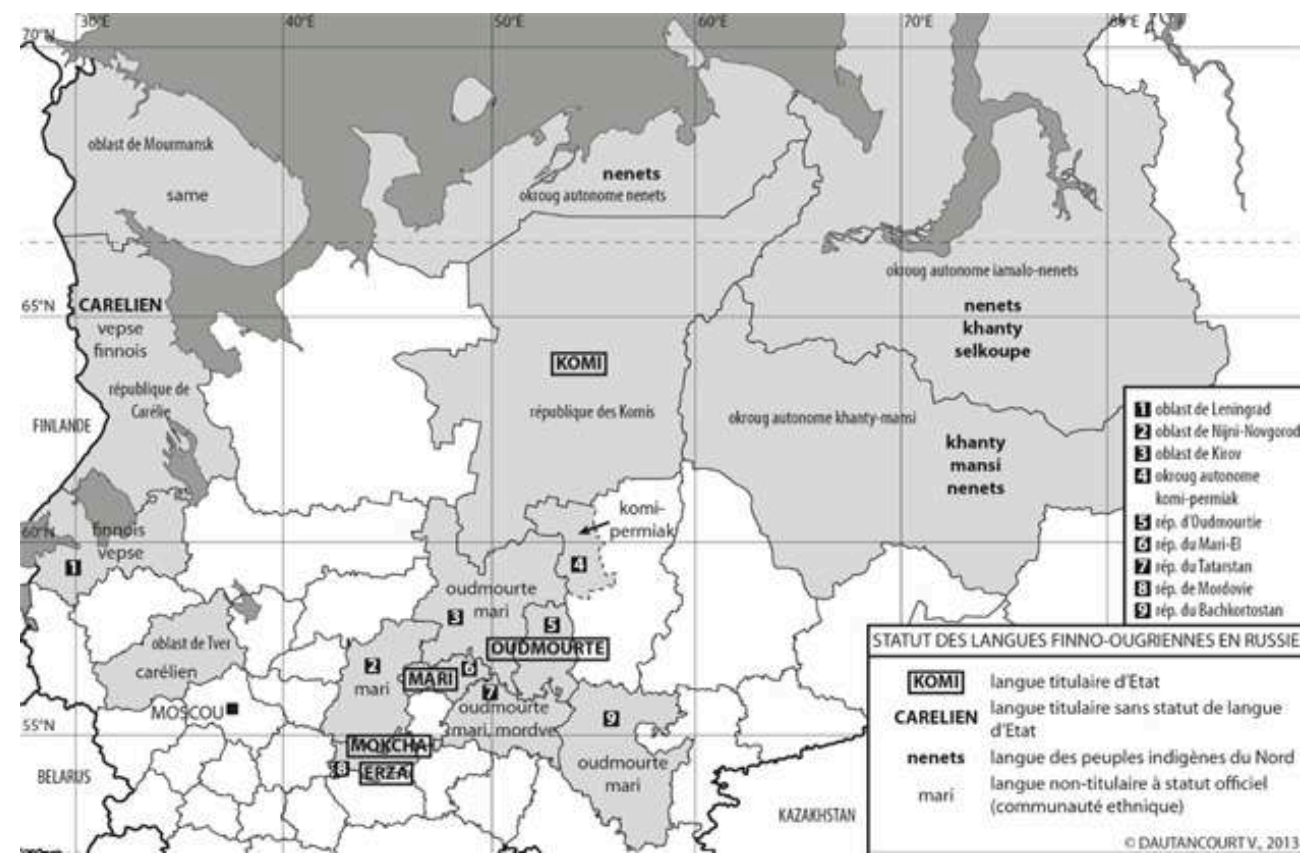

In the second section on the study data, the article will analyse the legal basis for language teaching in Finno-Ugric and neighbouring Turkic republics and the extent of use of three modes of their teaching. This section will also address the teaching of Finno-Ugric languages in non-titular regions and in autonomous districts. Despite the common education space, in the early 1990s regional authorities could and had to make important choices regarding the place of titular languages in education. As a result of these choices, language education is unique in each region. So far only succinct comparative overviews of regional legislations are available internationally (e.g. see Galdia 2009, pp. 9-11). In order to provide the basis for an extensive comparison, this study explores, from the legal-institutional perspective, a variety of regional legal acts and policy-defining documents approved since the early 1990s. The analysis will allow the author to reveal which choices the regions had for institutionalisation of their language revival policy within the established rules and means of their enforcement (see Kymlicka \& Grin 2003, pp. 5-7).

6 In the third section on the study results, the article will present an overview of the trends in language teaching and will discuss how various trends in dissimilar types of regions resulted in different access to native language teaching. In the conclusion, the 
study will summarise the argument that the regional frameworks of language education were important but also limited in time and scope mechanisms for reproduction of non-Russian language competence. The frameworks in dissimilar types of regions are comparable, although the access to native language learning was provided on a different scale. However, the federal policy shift at the turn of the millennium was followed by eradication of regional language revival projects. In particular, since the 2007 education reform, access to native language learning was falling in practically all regions, that is, even in those regions where the institutional position of titular languages was relatively stronger. The education reform started in 2007 by the Federal Law (1 December 2007) was continued by the new Federal Law on Education (29 December 2012), which, however, is not in the scope of this study because it is too early to speak about the effects of the latter. The outlined trends imply that already in one generation the absolute number of individuals reporting themselves as belonging to the Finno-Ugric peoples in Russia will plummet in time.

\section{Methods of calculation: from absolute numbers to relative share}

\section{Legal and institutional framework for non-Russian language teaching}

7 According to the principle of federalism and vertical division of powers, in Russia state policy formation is divided between the federal centre and regional authorities as the two major power levels. Federal legislation has supremacy over regional legislation and serves as a framework for regional policies. A study of regional developments would be very limited unless it addresses this general framework.

8 Since the Soviet period, native languages served as the media of instruction and were taught within the system of public education. Russia's Language Law (25 October 1991, Article 9) and Education Law (10 July 1992, Article 6) recognised the right of citizens to receive basic secondary education in their native language and choose the language of instruction within the range of possibilities offered by the education system as well as to learn it; the authorities have to ensure this right by establishment of the necessary number of corresponding education establishments, classes, groups, as well as by creating conditions for their functioning. It is remarkable that, according to the Russian Constitution (12 December 1993, Article 68), the federal state also guarantees all its peoples the right to preserve their native language and to create the conditions for its study and development. Therefore, the Constitution recognised both individual and collective language rights.

9 What is more, apart from recognizing the rights, legislation also established individual obligations to learn the state and native languages. The Language Law and later the Constitution (Article 68) established the Russian language as the state language of the whole country, which has to be learnt in all education institutions except preschool. The republics received the right to institute their own state languages. Article 10 of the Language Law states that the teaching of the state languages of the republics is to be carried out according to their legislation. Legislations of some republics established the compulsory study of their state languages. The other languages could be used in the official spheres of communication (i.e. including public education) in the areas of 
compact residence of the population according to the legislation (Article 3). Typically, in regional language laws the compulsory study of native languages was not established explicitly. The practice of compulsory native language teaching was established on the basis of administrative regulations.

10 That is to say, despite democratisation in education, both at federal and regional level, the policy-making approach and not the rights-based approach was taken to solve the language issues. Even those rights that were recognised were not self-executing, that is, cannot be invoked directly in court. In addition to the formal adoption of legal norms and recognition of some linguistic rights their implementation had to be further performed as an extended-in-time complex of administrative measures at the level of regions. That is why much was left at the discretion of bureaucrats and the role of regional education agencies -ministries or departments of education- was central in this.

11 Regional education agencies acquired competence to influence the language choices made by education institutions and to enhance the education process by taking a set of auxiliary measures. Their amount differed in extent from region to region and from republic to republic. Such measures typically included the creation of facilities for textbook publishing and teachers training as well as language teaching methodology. In all republics and some regions the scientific institutes of the development of national education were created during the 1990s in addition to the "institutes of the teachers' qualification upgrading" to provide scientific support for elaboration of methodology, textbooks and supply materials. New departments were opened in higher and secondary professional education institutions for training of mother tongue teachers. These bodies were responsible for reporting on advances in the language revival and employed certain criteria of evaluation. These measures, which largely influence the quality of education, are not in the focus of this research, which is restricted rather to the institutional choices regions made.

In practice, the teaching of non-Russian languages in Russian education was arranged in one of the three modes of language teaching: native language of instruction, native language as a subject and state language as a subject. Using these institutional settings the regional authorities took advantage of the possibility to adopt in their legislation the policy of language revival in education as a reaction to language shift and assimilation. The policy goal became an extension of the compulsory native language teaching to all students of the relevant nationality. In addition, the regional authorities could decide on issues relating to the following: whether the state language of the republic has to be taught as a compulsory subject to all students; or whether the native language has to be taught only as a subject or be used as a medium of instruction for all students of the titular nationality. The answers to these two issues depended much on sociolinguistic factors such as the proportion of the titular group in the population and are discussed in the following paragraphs.

13 An analysis of the regional policy profiles as an outcome of political bargaining is not in the scope of the current study. Furthermore, the study is limited to a policy analysis and does not claim to provide an answer to normative questions such as whether minority language education should be compulsory or voluntary (on different possible approaches, see Kymlicka \& Grin 2003). The study assumes, however, that an answer to this normative question in choosing policy goals would, by its adoption, lead to certain 
outcomes not only in policy implementation but also in the selection of certain criteria for evaluation.

\section{Evaluation of collective demands as an official criterion} the evaluation of language policy in education are, in the first place, the language attitudes in society at large, its readiness to invest in maintaining its multilingualism, and the approaches of various actors in language planning and participants in the education process. The actors in language planning are federal and regional authorities, regional education bodies and education institutions (see also taxonomy in Khruslov 1998, p.123). Children, their parents and teachers are participants in the education process (Provisions, 19 March 2001, p. 44). The large number of actors and participants poses not only the problem of what language policy should be adopted, but also of how to select the criteria for evaluation of language planning in education, be it in the republics or in other subjects of the Russian Federation. diversity as a value and stipulate the collective dimension in the promotion of languages. The Russian Constitution established everyone's right to freely choose the language of instruction (Article 26); this right is usually exercised by choosing an education institution with the native language of instruction. Indeed, citizens may have individual linguistic rights but are not obliged to exercise them. Yet, the Constitution also guarantees the right of peoples of Russia to preserve and develop their languages, and to be provided the conditions for their study and development (Article 68), that is, provides a group right, which can be effectively exercised only together with other members of a linguistic community -a 'nationality' or a 'people of the Russian Federation'.

The problem of who exactly is the bearer of group rights arises. "The peoples of the Russian Federation" is an official term used to refer to ethno-linguistic communities historically incorporated in the Russian state as either territorial or national-cultural (non-territorial) autonomies. Those communities that were incorporated territorially are officially referred to as "the titular peoples" of national republics or autonomous districts. As a rule, their languages are designated with official status in the republics' legislation and are better protected than those of peoples who have no administrative units of their own. The term 'national minority' is not used in legislation, while in public discourse the term 'minority' is sometimes applied narrowly to describe communities without their titular administrative units.

The use of the term "the rights of peoples" in both federal and republican legislations provides ground for selecting a criterion that represents the collective demand of linguistic communities. By these settings, the conditions for ensuring the constitutional right of the peoples to preserve, study and develop their languages must be made available by the state authorities. Therefore, a criterion lobbied by national revival organisations and used hitherto by republican ministries of education incorporated a collective dimension; it aims to increase the demand level to that of supply, and subsequently extend the supply, and stipulates the corresponding acquisition and language prestige planning. This criterion addresses the demands of "titular peoples of the republics" at the regional level and "peoples of Russia" at the federal level. This 
criterion is applied in some republics, like Tatarstan, Bashkortostan and Sakha (Yakutia), and also to 'non-titular nationalities'. When put into practice this should mean providing all members of linguistic communities with access to training and/or instruction in their native languages.

A somewhat different logic is behind the compulsory teaching of titular state languages to all students, both native and Russian-speakers. The Russian Constitution establishes the Russian language as the state language of the Russian Federation (Article 68), giving it a more privileged status against that of the state languages of republics. In addition, as regards the former autonomous republics of the RSFSR (unlike most former union republics of the USSR), both their titular language and Russian were declared as their state languages. This concerns all the Finno-Ugric republics except Karelia. The parallel status of two state languages was predetermined since these republics were designed as established at the will of their "multinational peoples". With the exception of the Republics of Tuva and Chechnya, where the titular language was designated and functioned for several years as the sole state language, in the former autonomous republics both titular and Russian were designated as the state languages in the early 1990s. They were considered as the elements of their national statehood of the titular peoples or/and the attributes of a multinational community (see Zamyatin 2013, pp. 711).

19 This situation also provided the rationale for compulsory teaching in these republics of both state languages to all pupils irrespective of ethnic origin. In some cases, e.g. in Tatarstan, state-language teaching was organised on the principle of parity, that is by dedicating identical numbers of hours to all language teaching (Leontiev 1995, pp. 6970). Today Russian experts deny equality of state languages and the formula 'equal rights of languages' of Russia's Language Law, arguing that languages are 'equal' only in their status as 'native languages' (Tishkov et al. 2009). Even though officially the teaching of the state languages still 'can be introduced', also according to the new Federal Law On Education (29 December 2012, Article 14), in practice their compulsory teaching started to be removed by gradual enforcement of the Federal State Education Standards also in Volga Turkic Republics by (Zamyatin 2012a; see the data on Bashkortostan at the end of this paragraph).

\section{Absolute and relative indicators in official evaluation}

21 How have collective demands been officially evaluated? Authorities traditionally use formal quantitative criteria. The absolute data are provided both at regional and federal level on the number of education institutions where languages other than Russian are taught or used as the medium of instruction, and the absolute numbers of pupils studying their native or state language. Additionally, the numbers of published textbooks and trained teachers of mother tongue are sometimes given.

The republics that have not established compulsory study of their state languages to all students typically report only the absolute numbers of schools and schoolchildren studying their native language. Their approach is that all students of the titular ethnic origin there had to learn their native language. The problem in the determination of students' ethnicity appeared in 1998, when the ethnic origin of citizens stopped being recorded in Russian internal passports, so the ethnicity of schoolchildren cannot be viewed as constant but may vary. Moreover, under the recent anti-discriminatory measures the ethnic origin of schoolchildren has been classified as personal 
information not to be disclosed and sometimes not even to be registered at school (Federal Law, 27 July 2006; Ossipov \& Sapozhnikov 2004).

More information could be found in those republics that have established compulsory study of state languages to all schoolchildren. Figures are produced on the total number of pupils studying state languages and the number of schools teaching them, for instance, in Komi and Mari El. The percentage of pupils studying titular or native languages, if counted, is typically stated in relation to the total number of schoolchildren in the region, which includes Russian-speaking children. As the experience of the current study as well as other research studies witnesses (Stepanov 2011, p. 251), these data are often inaccessible, because the authorities are quite reluctant to make them public arguing the sensitivity of ethnic issues. Researchers from regions sometimes get access to the data from the archives of the ministries of education, but it is much more difficult to collect cross-regional data. This explains why little systemic research has been done so far in the Finno-Ugric republics. In contrast, the Tatarstan and Bashkortostan authorities regularly provide the data on the relative share of students learning native language not only of titular but also of regional minority populations. The problem with absolute indicators is that more often than not, the practice of evaluation based on formal criteria does not reveal the actual trends characterising the situation of languages in education.

Periodically the federal authorities provide the data based on relative indicators, such as the percentage of schools teaching titular or native languages. The latter, however, does not reveal the real situation, either. Sometimes the official data may even bear marks of attempts by the authorities to stretch the truth, when the regional data are aggregated at the federal level. For example, it has been reported that languages other than Russian are taught in more than a quarter of schools in Russia:

There are 6,260 general education institutions applying native languages in the education process in the Russian Federation (9.9 per cent of the total), and 10,404 schools where native (not Russian) languages are taught as a discipline (16.4 per cent)... Today, in about 20 per cent of Russian general education institutions monoethnic contingents of students are being taught in their native languages (Russia's Second Report 2005, pp. 28-29).

Now, it must be emphasised here that the reported $20 \%$ is the share of students having native (non-Russian) language of instruction among students learning their native languages. The share of schoolchildren learning native languages among all students is almost a half less (13.5\%) than the share of schools among all schools providing native language teaching in Russia (26.3\%). In the current study this divergence between the numbers of schools and students was observed as typical for the data from the FinnoUgric republics. For example, in the academic year 2010-11, only 32,023 out of 94,304 the total number of students in the Komi Republic studied Komi as a subject, or about $34 \%$ of all students, but the teaching of the Komi language was organized in 255 out of 399 general schools, or in about $63 \%$ of schools (Information and Statistical Materials 2011, pp. 33-35). In Udmurtia, in the academic year 2011-12, the Udmurt language was taught in 341 schools ( $56 \%$ of all schools) to 20,229 students (14\% of all students) (UR Ministry of Education 2012). In Tatarstan native language schools are not only Tatar national schools but also mixed schools with parallel classes of instruction in Tatar and Russian.

The divergence originates from the circumstance that it is enough for a school to have only few pupils studying their mother language, for example, to have a national class, 
to be counted as providing the language teaching. Native languages are typically taught in small rural primary schools or in separate classes of urban schools. Therefore, the number of schools in a region listed in official reports as having language teaching does not disclose, but rather conceals, the information on what share of schoolchildren have access to education. Even less informative are the aggregated data on the number of languages used in the education system, which is a primary indicator of use both in official federal reports on the situation of languages (e.g., Russia's Third Report 2010 or Russia's State Council Report 2011) and in semi-official sources (e.g., see Tishkov et al. 2009). Indeed, it is enough for a language to be used at least in one school in Russia for this language to be listed as a language used in education system (see Zamyatin 2012a, pp. 20-22).

\section{Evaluation of individual demands as a new official criterion}

27 Today, there are still two indicators officially approved in Russia as possible criteria to measure the efficiency of language policy in education; these are the satisfaction of linguistic education demand of (1) the citizens, and (2) the peoples of Russia (see Concept of the National Education Policy, 3 August 2006). Yet, the "satisfaction of ethnic-cultural and linguistic educational demands of the citizens of poly-ethnic Russia" was introduced as the main criterion. This criterion differs from previously used collective demand criteria in that it stipulates reducing the level of supply to the level of demand and would further lead to the reduction of demand. In the reformed system the supply of the teaching of native languages in the republics may in many places exceed the demand. Previously the non-Russian languages could be used as the native language of instruction and native language teaching as a subject within both the mandatory and variative part of the school curriculum. The education reform of 2007 transformed the mode of native language teaching by giving the schools the decision over it within the variative part of the curriculum. This transformation itself reduces the demand, because of the lowered place of language education in the education system. Application of this criterion would produce in the long run indications of a much lower demand than that obtained by applying ethnic and linguistic self-identification of pupils, a method used in population censuses and sociological research studies ordered by authorities of the republics. Moreover, the language revival agenda, which operated through extending the network of schools teaching native languages, is taken completely off the table.

The reduction of supply is implemented covertly through a campaign for "optimisation" of the school system announced prior to the reform and justified by the need to ensure availability and high quality of education in the conditions of demographic recession (RF Government Decree, 17 December 2001; Priority Directions, 9 December 2004; RF Ministry of Education Orders, 16 January 2002 and 25 May 2007); inter alia, the principle of per-pupil funding leads to closure of small rural schools. ${ }^{2}$ Yet, these are exactly the schools were the non-Russian languages are mostly used. For example, in Komi only between the years 2007 and 2011 the closure of small rural schools led to a drop in their share among all schools from $66 \%$ to $51 \%$ (Education in the Komi Republic 2010, 2011); in Mordovia between 2007 and 2010 from $68 \%$ to $60 \%$ (Statistical Data and Indicators 2010; see Zamyatin 2012b). The number of small rural schools is significant and despite their continuing closure still counts for notably more than a half of all schools in Russia. The data on the number of schools are often 
available, but not analysed in the current study. A separate study focused on the dynamics in the number of schools and their types could be helpful in further testing the argument that so far the dynamics in language education was determined first of all by closure of small rural schools.

Alternatively, the reduction can take place openly through the children's and parents' decision. According to the proposed scheme, the children's demands should be measured by statistically monitoring the requests of parents to have the native language among subjects taught to their children at school. In other words, only the expressly stated demands of children and their parents would count, but not children's ethnicity as previously (Kuzmin \& Artemenko 2010, pp.44-46). Still, ethnicity continues to play its role, because one's native language is determined by ethnicity; one cannot pretend any language to be native and, thus, express linguistic demand to study any language one likes from among the peoples of Russia. Native language is taught both to those with language knowledge and those without it. How to prove one's belonging to an ethnic group in conditions where the ethnic origin of citizens is no longer officially indicated? According to the proposed scheme, the parents themselves have to express linguistic demands based on their ethnicity. The issue of too high a threshold of sufficient demand becomes central.

Language learning can be organised at the class level and pupils fill rates per class have to be met. The fill rates of 25 pupils in urban and 14 pupils in rural schools are marked as optimal indicators of effectiveness of regional authorities (RF Government Decree, 15 April 2009). In fact, establishment of smaller (and not bigger) classes is allowed but discouraged by a mechanism of per-pupil funding. Further, dividing the class into two subgroups for the purpose of language learning is allowed in schools with native language of instruction, but even in that case a class in a rural school should have a minimum of 20 pupils (Provisions, 19 March 2001, paragraph 26, 31). Sometimes one of subgroups learns the native language and the second learns some other subject. By this high threshold it would be realistic to satisfy the linguistic demands only in the areas with dense minority populations. Thus, the group vulnerable to denial of linguistic demands is pretty big.

In a region where the population is mixed and study of the titular languages is not compulsory, the reformed education system would confine the teaching of these languages mostly to rural areas with dense native populations. This way the fact would escape attention and proper estimation that a large segment of children of non-Russian ethnic origin, particularly in cities and towns, is stripped of the possibility to study their native language. The alternative possibility is to establish linguistic demand by the actual language knowledge of children, which is even narrower because it excludes children of a certain ethnic origin without language knowledge.

Therefore, it is assumed that parents and children will actively express their need for language based on ethnicity. The motivation of parents and children in language learning becomes the central issue for initiating language teaching. The recently conducted sociological research studies in the Finno-Ugric Republics witness the fact that in general a significant number of parents are in favour of teaching the native language to their children (Etnokulturnoe obrazovanie 2010, Pravovoi status 2011). However, the overall linguistic situation does not provide incentives to learn stigmatised minority languages. A further problem is that it is highly unlikely that average parents would insist on their rights in the field of education in conditions 
where ethnicity has been otherwise undermined throughout the public sphere during the last decade through anti-discriminatory campaigns (see Ossipov \& Sapozhnikov 2004).

33 Furthermore, the issue of the discriminatory character of the obligation to learn the native language has been raised in court by the regional Public Prosecutor's Offices in some republics. In Adygea the Supreme Court reached a decision in 2006 that the demand for compulsory native language learning for all Adyge schoolchildren in the regional education law is in contradiction with the federal legislation and, thus, void (Decision, 19 December 2006); in Mordovia in January 2010 the Public Prosecutor's Office directly requested that schools remove native language teaching from the mandatory part of the curriculum (Press release, 2 February 2010). For the developers of the reform discrimination this was not a central element of the argument in support of the free choice of language learning; they were rather concerned with the unification of Russia's education space and reached it merely by reassignment of native language learning to a variative part of the curriculum.

From an anti-discriminatory perspective, developers of the reform challenged the compulsory study of titular state languages of the republics by referring to the 'alarming rise in the number of complaints filed by members of the public with the state authorities and the courts' on this issue (Tishkov et al. 2009, pp. 37-38). After the debates and compromises on the abrogation of components of the education standard, in line with Russia's 2004 Constitutional Court decision, it has been formally agreed that republics may continue teaching their titular languages as state languages within the obligatory part of the curriculum (Kuzmin \& Artemenko 2010, p. 46). The teaching of the state languages of the republics, despite the new Federal Education Law, is still regulated by the republics' own legislation. So far the republics may themselves establish the teaching of state languages by passing respective laws. Among the FinnoUgric republics Komi, Mari El and Mordovia have formally retained the compulsory teaching of their titular state languages to all schoolchildren.

Since the new federal education standards entered into force, formal provisions on compulsory state languages study also stopped being reflected in the practice of the Volga and Ural area Turkic Republics. For example, in Bashkortostan, since 2009 it has not been compulsory for children to learn the titular state language. According to Ministry of Education data, between the academic years 2009-11 and 2011-12 the share of students learning Bashkir either as a native or state language among all students dropped from $98.5 \%$ to $87 \%$; this is because it is not taught to the children in the first and second grades whose parents are against it. A significant decrease in the share of state language learners within a few years could easily be predicted. Therefore, in the Finno-Ugric republics not all pupils are taught their native, nor are they taught the state languages, while in the Volga- and Ural-area Turkic republics not all students receive native-language instruction, nor do they all study the titular state languages. This gap between formal provisions and practice implies the need for an evaluation of efficiency of language policy in the republics and selection of its criteria.

\section{Study method and the evaluation criterion of this study}

It is paramount to properly select the criteria for evaluation of language policy in education, and the key question is whether the demand or the supply should be used as 
the indicator of satisfaction of the education demands of peoples and individual citizens. These criteria do not contradict each other, but imply the different measures to be taken. In any case, the preference of the criterion based on individual demand stipulated by the education reform did not invalidate the obligation of the State to "provid[e] conditions for satisfaction of ethnic-cultural and linguistic educational demands of the peoples of Russia". That is why in this study, evaluation is based on the latter criterion. The focus of the analysis is on the linguistic demands of communities, first of all, in republics. Young members of these communities, supposed to have linguistic demands in education, are referred to throughout the article as "schoolchildren/pupils of titular nationality/ethnic origin". Therefore, this study is not confined to comparing the absolute numbers of schoolchildren of titular origin who study their language as a state or native language, but instead is focused on calculating relative shares of native language learners among all schoolchildren of titular origin. Accordingly, the relative share of those of them who have access to study their language in any of the three teaching modes is used as the quantitative indicator to analyse changes in the volume of language teaching.

\section{Sources, study method and shortcomings of its varieties}

37 Education is the most sensitive and transparent field for evaluation of the success or failure of language revival. Following the examination of the regional institutional solutions directed at language teaching extension, the study explores how these solutions were implemented in the three modes. In order to elucidate adequately the implementation, the study assesses the policy effect by following the data on the dynamics in the relative share of native language learners in school. Unless available in official sources $^{3}$ (this are often reports from regional education agencies) or in expert evaluations, the share of the students of a titular nationality is calculated by comparing the absolute numbers of language learners with the absolute number of titular students among all students of a region (the latter data available in Rossiiskii 2011); the number of students of titular ethnic origin is found based on the share of the titular groups in the total regional populations according to data from population censuses (Natsionalnyi sostav 1989, 2002, 2010). ${ }^{4}$ In the analysis, only the data on the years with five-year interval are examined: 1990, 1995, 2000, 2005 and 2010; data on other years are quoted only if indicative of certain processes. This timing roughly reflects both the historical frame and the population census arranged each tenth year, providing the statistical background for research. In order to avoid unnecessary extra detail, this study takes the share of the titular groups in a republic's total population as a constant for the decade following the population census, even if (with some exceptions) actually this share slowly decreases.

38 Any version of this method can produce approximate data only, inter alia, because schoolchildren of other nationalities are sometimes also among those who study titular languages as the "state language" or even as the "native language", although learners of the titular language are either typically those of titular ethnic origin (see Zamyatin 2012b, pp.81-83). A quantitative analysis based on absolute figures is further complicated by the fact that, according to official data (Federal Programme, 7 February 2011), the total number of schoolchildren in Russia dropped by more than $40 \%$ during the 2000-2010 decade, owing to the lasting demographic recession (see Zamyatin 2012b, p. 94). A structured analysis is needed to find out what is the impact of 
the language education policy behind demographic factors. Any version of this method also has an inherent drawback: the deformation of an age-sex graph by the reduced proportion of children, typical of national minorities, is neglected in calculation. For example, according to expert evaluation in Karelia instead of $15 \%$ statistical share of people aged 7-17, the share of Karelians was only 9.8\% (Klementiev 2006a, 2006c).

\section{Restrictions of the method}

One difficulty for the study is that often the data on schools and pre-school institutions are quoted together. Indeed, the pre-school education is particularly important for teaching Finno-Ugric languages. For example, although there are no schools with the native language of instruction in Udmurtia and Karelia, kindergartens have been established in these republics, which use native languages in children's upbringing. In Karelia, the 'language nest' technique was used in a few pre-school institutions (Pasanen 2003); some regional authorities planned application of this method to be extended to kindergartens in the other Finno-Ugric regions. However, the federal authorities assessed this technique as imposing 'segregation of children on ethnic grounds' and refused to use it (Russia's Third Report 2010, pp. 102-103). Although the use of languages in pre-school institutions is an important topic deserving separate analysis, due to lack of space it is not discussed here. For the purpose of this article the data on schools and pre-school institutions have been separated wherever possible. According to the obtained data, on average, kindergartens using native Finno-Ugric languages in upbringing are provided on a lesser scale than schools.

41 The comparison of regions is also complicated by the inconsistency of the data available. In the reports on language teaching, for instance, the education authorities of some regions may present the figures on compulsory and optional study of titular languages as one aggregate figure. This might be one of the reasons for divergence between the federal and regional data. For this study, the data reported by regional authorities were preferred whenever accessible. As the sources of these data are closer to the grass-roots level; they are usually more accurate than those produced by the Russian Ministry of Education (Strogalshchikova 2008, p. 229, citation 14). Regional data are also valuable because, in some cases, they provide information on the share of learners of the titular language in certain modes among the total number of schoolchildren in the region or even in the whole ethnic group. Apart from the inconsistency of data, data may contain errors or even false figures. Typically, all other factors held equal, official data tend to present a better picture than is actually the case because they omit such circumstances as the absence of a teacher or a lesson despite their presence in reports, etc.

In addition, qualitative variables were excluded from consideration as well. The language competence of children entering school varies from a total lack of knowledge to fluency, depending on their family background and sociolinguistic situation. Further, the quality of teaching varies depending on the availability and quality of 
textbooks and supply materials, on the quality of teacher training, and on methods of teaching. Finally, the language competence of school graduates varies from a total lack of functional communicative skills to fluency, depending on the quality and amount of teaching. To adequately evaluate linguistic skills, a qualitative study should include in a set of variables the issue of language testing. All this impairs the accuracy of evaluation. Omission of some qualitative and quantitative variables tends to compress the confidence interval, making the results open to further discussion. "The available information allows tracing only the [general] tendencies in application of Finno-Ugric languages in the education system" (Strogalshchikova 2008, p. 150). It is nevertheless possible to compare the amount of language teaching in different republics because, as was noted above, Russia's regions have a unified education system.

\section{The study data: application of three modes of language teaching in Russian regions}

\section{Teaching of the state and native languages in Finno-Ugric republics}

According to population censuses, there was a decrease in population of all Finno-Ugric republics over the last two decades. In addition, the relative share of the titular groups in the total population of some republics drops, as can be seen from Table 1. Yet, the significance of the republics and their education systems for language maintenance cannot be underestimated. The retention rates of Finno-Ugric language are higher among those living in the titular republic. According to the 2010 population census, within the borders of their titular republics are $74.9 \%$ Karelians, $88.7 \%$ Komi, 53.1\% Mari, $44.8 \%$ Mordvins and 74.3\% Udmurts.

Table 1. The titular populations in the Finno-Ugric Republics

\begin{tabular}{|l|l|l|l|l|l|l|}
\hline Republic & Komi & Mari El & Mordovia & Udmurtia & Karelia \\
\hline \multicolumn{7}{|l|}{ 1. Total population of the republic } \\
\hline Census 1989 & 1,251 & 749 & 963,5 & 1,605 & 790 \\
\hline Census 2002 & 1,018 & 728 & 889 & 1,570 & 716 \\
\hline Census 2010 & 901 & 696 & 834 & 1,521 & 643 \\
\hline 2. Representatives of titular groups in republican populations \\
\hline Census 1989 & 291 & 324 & 313 & 496 & 79 \\
\hline Census 2002 & 256 & 312 & 283 & 460 & 65 \\
\hline Census 2010 & 202 & 290 & 333 & 410 & 45 \\
\hline 3. Share of titular groups in the total population of the republic \\
\hline Census 1989 & $23.3 \%$ & $43.3 \%$ & $32.5 \%$ & $30.9 \%$ & $10 \%$ \\
\hline
\end{tabular}




\begin{tabular}{|c|c|c|c|c|c|}
\hline Census 2002 & $25.2 \%$ & $42.9 \%$ & $31.9 \%$ & $29.3 \%$ & $9.2 \%$ \\
\hline Census 2010 & $23.7 \%$ & $43.9 \%$ & $40 \%$ & $28 \%$ & $7.4 \%$ \\
\hline \multicolumn{6}{|c|}{ 4. Share of individuals reporting their language knowledge in the republic* } \\
\hline Census 1989 & $74.4 \%$ & $88.4 \%$ & $88.5 \%$ & $75.7 \%$ & $51.5 \%$ \\
\hline \multicolumn{6}{|c|}{ 5. Representatives of the titular group in Russia } \\
\hline Census 1989 & 336 & 644 & 1,073 & 715 & 125 \\
\hline Census 2002 & 293 & 604 & 843 & 637 & 93 \\
\hline Census 2010 & 228 & 548 & 744 & 552 & 61 \\
\hline \multicolumn{6}{|c|}{ 6. Share of individuals reporting their language knowledge in Russia* } \\
\hline Census 1989 & $71.0 \%$ & $81.9 \%$ & $69.0 \%$ & $70.8 \%$ & $48.6 \%$ \\
\hline
\end{tabular}

Sources: Natsionalnyi sostav 1989, 2002, 2010; Finno-ugorskii mir 2008; Lallukka 1990.

\section{* IN THE LAST 1989 SOVIET CENSUS THERE WAS A SEPARATE QUESTION FOR NATIVE LANgUAgE; IN} 2002 AND 2010 ALL-RUSSIAN CENSUSES ONLY ASKED FOR KNOWLEDgE OF LANgUAgES.

As most national republics, Komi, Mari El, Mordovia and Udmurtia designated their titular language(s) and Russian as their state languages (but not Karelia). Among them only Komi and Mari El introduced, in the early 1990s, the compulsory study of the titular state languages by all students irrespective of their ethnicity. Behind the apparently unambiguous term "state languages of republics" we can thus see realia of various kinds, notably in the area of education. Despite the official status, a separate decision on the compulsory study of titular state languages was needed. The goal for this latter move was arguably to create communities that would be truly bilingual by ensuring its members' language competences for two-sided language choices.

If a region, irrespective of its ethnic minority being densely or disparately settled, represents a historically integrated poly-ethnic and poly-cultural space instead of an administrative territory with borders drawn in a purely arbitrary manner, or to put it another way, if the Russian and non-Russian ethnic groups have been living in close cultural interaction over many decades or centuries in that region, then the mutual alternate use of respective languages by the same people plays an essential social role, [and therefore] both languages should be used to an adequate degree in education at the local level to all schoolchildren, and not only those to whom the respective language is native (Dyachkov 1993, p. 114, author's translation).

A low social status of de facto minority languages and one-sided bilingualism of minority members were the greater obstacles for this undertaking. Unsurprisingly, the compulsory learning of the state languages of republics was from time to time under challenge on the side of parents. Already as far back as 2002, the Constitutional Court of the Komi Republic ruled that the compulsory teaching of both state languages was compliant with the Constitution of the Republic:

The Introduction of compulsory teaching of the Komi language in secondary schools must be carried out in the presence of appropriate conditions for quality training, insofar as the binding character of language teaching means 
constitutionally and legally, above all, the responsibility of the state authorities and local self-governments authorities to ensure the teaching standards appropriate for development of personality, talents, intellectual and physical abilities of a child to the fullest extent (Judgement, 22 May 2002; author's translation). Education Law as a reaction to the 'alarming rise in the number of complaints filed by members of the public with the state authorities and the courts' on the issue of compulsory titular language learning. The following statement from Tatarstan was represented as a typical complaint:

Pupils in our schools spend 5 to 6 hours a week studying the Tatar language, at the expense of core subjects (Russian, literature, mathematics and, in the senior years, physics and drawing). To give an example, 5 hours are spent studying Russian language and literature instead of 8 hours. Neither the children nor the parents are happy with this situation. We are not against our children studying the Tatar language, but the classes should be limited to 2 hours per week or else made optional. After all, there are specialist schools in the republic for anyone who wishes to study the native Tatar language in greater depth. The curriculum is seriously flawed, with the result that pupils end up knowing neither Russian nor Tatar. And this has been going on for many years. Parents are obliged to pay private tutors to tutor their children in the core subjects from year 1 onwards. We live in Russia and are a subject of the Russian Federation, so why should our children be educated differently? (Tishkov et al. 2009, pp. 37-38).

Nevertheless, the reform seems not to have directly affected the institutional position of state languages of republics in education. After the long debates and compromises on the abrogation of components of the education standard, it has now been established 
that republics may carry on teaching their titular languages as state languages within the mandatory part of the core curriculum (Kuzmin \& Artemenko 2010, p. 46). The most recent similar decision on the compulsory study of the titular language by all students reached the Constitutional Court of the Komi Republic (Judgement, 1 September 2011).

\section{Komi Republic}

50 start language revival without delay: the department of national school was created in the Ministry of Public Education in 1988 (Gabov 2006); in 1995 it was transformed into the department of national education systems and rural schools. The department elaborated the Law on State Languages of the Komi Republic, which says that "Komi and Russian state languages are taught in all secondary schools in the Komi Republic" (KR Law, 22 May 2002). The regional Education Law of 1993 (KR Law, 28 December 1993) duplicated the respective provisions of the federal Education Law of 1992 in regard to languages. In amendments made to the Komi Education Law in 1998, the policy of gradual transition to compulsory teaching of the Komi language to all schoolchildren up to the seventh grade was confirmed. These amendments contained a provision for the teaching of Komi as the state language to be introduced within seven years (KR Law, 27 February 1993).

51 The available data allow us to evaluate developments in the teaching of Komi in absolute figures across the whole number of schoolchildren in the Komi Republic. In 1986, prior to perestroika and the reforms that followed, there were 14,200 pupils studying Komi (Gabov 2009, p. 137). In the academic year 1990-91 their number rose to 19,500 , of which 15,890 were studying Komi as the native language and 3,843 as the state language; this made nearly $10.5 \%$ of the total number of 201,000 schoolchildren in the republic in that year. At that time, according to expert estimates, about $40 \%$ of pupils of Komi origin were taught their language (the official data on absolute numbers and, sometimes, shares of language learners in 1990 in all three modes for the FinnoUgric republics are available in Strogalshchikova 2008, pp. 150-151). In the academic year 1994-95, Komi was studied by 17,568 pupils as the native language and by 10,797 as the state language, making up $16.6 \%$ of all schoolchildren in the republic (Popov \& Nesterova 2000; Tsypanov 2001, p.189). The Komi Ministry of Education gives the figure of 31836 or $17.6 \%$ of all schoolchildren for that year (Sadovskii 2000, p. 25). In 19992000 , Komi was studied by 16,926 pupils as the native language and by 21,224 as the state language; this was $20.2 \%$ of the total amount of 169,000 schoolchildren in the republic (Sadovskii 2000, p. 25), but more than half of Komi schoolchildren (about 52\%, according to our estimation) were covered (Strogalshchikova 2008, p. 150; Kozulina 2003, pp. 255-256; Gabov 2009, p. 157).

52 It is worth noting that, unlike in other republics, Komi was taught as the state language for three instead of two hours per week (Ministry of Education, 12 April 1999; Sadovskii 2000 , p. 28). However, the important change came at the beginning of the 2003-04 academic year, when Komi as a native language started to be taught for three instead of five hours per week and Komi as a state language for one instead of three hours (Mosin 2006,2010, p. 175). A slow growth in the share of pupils studying Komi among all pupils in the republic continued throughout the first decade of the new century. In the 200405 school year they numbered 40,514 ; their share was $32 \%$ of all schoolchildren in the 
republic and was growing at the rate of one to two percentage points per year (Gabov 2006, p. 100; Gabov \& Popov 2010, p. 34).

The new Education Law of the Komi Republic contained no provisions regarding languages (KR Law, 6 October 2006). A month later it was amended with a new article regulating language issues (Article 1.1). The article, among other things, restored compulsory teaching of both Komi and Russian as state languages in all education institutions. Until recent years, teaching of Komi had been gradually extending. In the 2009-10 academic year the absolute number of pupils studying Komi decreased to 35,278 ; however, their share grew to $38 \%$ in the total amount of 97,000 schoolchildren in the republic due to the continuing demographic crisis (KR Report, 2010). Komi was studied as the native language by only 6,200 pupils (6.5\%) at 110 schools, and as the state language by less than 28,000 pupils (31.5\%) at 161 schools (Popov 2010). At the end of the considered period still more than half of Komi schoolchildren (about 55\%, according to our estimation) studied their language.

Notably, unlike the other Finno-Ugric republics, the share of students learning Komi in urban schools is significant due to the fact that children of all nationalities have to learn it as a state language. Additionally, throughout the observed period less than one thousand students learned Komi as an optional subject (Education in the Komi Republic 2010, 2011). It should be noted that the mode of teaching as the state language is intended primarily for those pupils who lack a good command or even any knowledge of the language; this cannot but influence the linguistic competence the students finally acquire.

\section{Mari El Republic}

In the Republic of Mari El, phase-by-phase introduction of compulsory teaching of Mari as the state language was also planned initially. This was first stated in the regional Education Law (RME Decree, 4 November 1992) with a stipulation providing temporary suspension of this transition. Later this goal was reaffirmed by the regional 1995 Law on Languages which established the gradual introduction of teaching Mari as the state language "within five years as the personnel is trained and the relevant educationalmethodical complex developed" (Articles 11 and 62, RME Law, 26 October 1995).

In the 1990-91 academic year, out of the total number of 116,000 schoolchildren in the republic, Mari was taught as the native language to 27,700 (according to our estimation, about 55\% schoolchildren of Mari origin, including with instruction in Mari). In 199596 the numbers of pupils studying Mari as the native and the state language were respectively 29,730 and 21,256 or $38.8 \%$ of 131,000 students (Kudriavtseva \& Shabykov 2002, pp. 42-43); according to an official source, it was taught in these modes to a total of 39,900 or $69 \%$ of schoolchildren of Mari origin (State Programme of RME, 25 July 1995). In 2000-01, Mari was taught to 25,974 pupils as the native language and to 46,559 as the state language; this made up the total of 72,533 or nearly $60.3 \%$ of 120,000 schoolchildren in the republic (Kudriavtseva \& Shabykov 2002, pp. 42-43). According to our estimation, among the schoolchildren of Mari origin, the number of those who studied Mari in either mode rose to about $82 \%$.

However, language policy in Mari El was changed in 2001 with the election of a new president who appointed a new Minister of Education. The department of national problems of education in the Ministry of Education was created in Mari El quite early, 
too, but had already been abolished by 2001 (Salo 2005, p. 112). Compulsory teaching of state languages of the republic was abolished by a new law adopted in 2001 (Article 6, RME Law, 9 April 2001, revised 3 May 2005 and 7 March 2008). As a result, the share of pupils studying Mari as the state language had decreased by more than ten thousand in the next academic year 2001-02 (Kudriavtseva \& Shabykov 2002, pp. 42-43). The mechanism that abolished compulsory language teaching was described by a researcher as follows: "the basic syllabus for secondary educational institutions, approved in August 2001 by the Ministry of Education of the Republic of Mari El, allows 17 different options of curricula for various kinds of education institutions. Only five of them include the study of Mari as a compulsory subject, and in the amount of two lessons per week. Bearing in mind that an education institution may opt for any option of the basic syllabus, this opens up ample opportunities to completely drop teaching the Mari language" (Dyachkov 2004). According to another researcher (Sharov 2002), "the number of pupils studying Mari in the Republic of Mari El decreased when the schools were entitled, pursuant to the legislation on education, free choice of curricula (including as regards teaching the Mari language)". The exacerbated situation in language teaching was among the causes of the conflict that emerged in Mari El and attracted international attention. "The widely known conflict in Mari El was triggered by statements made by the Minister of Education on the necessity of voluntary study of the Mari language at schools" (Strogalshchikova 2006, p. 26)

In this situation, the authorities of Mari El sought to disprove criticism but could rarely find data in their defence. This partly explains why the official data on the share of pupils studying Mari diverge from those supplied by independent experts. For example, the Political Information Department of the RME Presidential Administration reported that in the school year 2004-05 "over 80\% of the total number of pupils (in grades 1 to 9)" in the republic were studying Mari as the state or native language, "including practically all schoolchildren of Mari origin" (Part 6, Collection of Materials 2005, pp. 36-38). However, a more detailed analysis shows that in the indicated year Mari was taught in grades $1-11$ to 18,692 or $21.1 \%$ of all pupils as the native language, and to 19879 pupils as the state language, and additionally to 5,535 schoolchildren who attended the integrated course of Mari language, history and culture. Altogether $27 \%$ of pupils in grades 1-9 were taught Mari as the state language (IHF Report 2007, pp. 7071). Thus, the total share of those who were taught Mari in either mode was probably slightly more than half of 82,000 schoolchildren in the republic (about $53.8 \%$ ), whereas, according to our estimation, the share of those ethnic Mari students who were learning the Mari language rose to about $84 \%$.

According to the RME Education Ministry, in the academic year 2009-10, among 66 thousand schoolchildren in the republic, $17.6 \%$ were those who studied Mari as the native language and $44.4 \%$ as the state language: the respective absolute figures were 11,616 and 29,304 (RME Programme, 7 December 2010; RME Ministry of Education Report, 15 February 2011). It is important to note that today over half the children who study Mari are taught it as the state language. As one of the consequences, as with the Komi Republic, the share of language learners is significant for the urban schools. According to our estimation, about $84 \%$ of ethnic Mari schoolchildren learned their language in either mode. 


\section{Republic of Mordovia}

60 that a policy of language revival was officially adopted in this republic. Before that, in the academic year 1990-91, among 132,000 students in the republic, titular Erzya and Moksha were taught as native languages (including as the language of instruction) at "national schools" to 16,576 schoolchildren of titular origin (or $38 \%$ according to our estimation). In 1994-95, the Mordvin languages were taught to 15,540 schoolchildren (Kazimov et al. 2008, p. 56). This means that unlike the other republics, the share of the students learning the titular languages even somewhat decreased. The Law on State Languages (RM Law, 6 May 1998) and the Education Law (RM Law, 17 November 1998) were adopted. The former says that, "the Mordvin languages (Erzya and Moksha) may [sic!] be taught" in all education institutions. The reform has made the teaching of Mordvin languages (Erzya and Moksha) a topical issue in the Republic of Mordovia. Under this law, Erzya and Moksha were taught to 3,191 pupils as state languages in the so-called "Russian schools" in the academic year 1999-2000, in addition to 16,136 pupils who studied them as native languages at "national schools", out of total 132,000 students in the republic (Mosin 2005, p. 16; Shilov 2002). According to our estimation, this raised the share of schoolchildren of the titular nationality who were taught their own language in either mode to about $41.7 \%$.

61 In 2004 the RM Ministry of Education of the republic endeavoured to introduce compulsory teaching of state languages of the republic to all schoolchildren, including in urban schools where Mordvin languages were virtually absent hitherto (RM Ministry of Education Orders, May 20 and October 8, 2004). In practice, this attempt boiled down to letting schools decide themselves whether or not they would teach the local language as a compulsory subject (Shilov 2004, Shabaev et al. 2009). Nevertheless, in the academic year 2004-05 when the teaching of the Mordvin languages as state languages in "Russian schools" was first introduced, they were taught not only as native languages at "national schools" to 14,998 Mordvin children but also to other 8;626 children as state languages (although, e.g., in the town of Saransk their number was 25 only) (National Education 2005, p. 20).

By the academic year 2009-10 the situation reversed. Currently the Mordvin languages are taught mostly as state languages. The number of children studying Erzya or Moksha as the native language at senior, middle and junior school respectively for one, two and three hours per week shrank to 7,670 (see Network of Schools 2009), while there were already 15,493 children studying Mordvin languages as state languages. Out of the total number of 69,743 schoolchildren in the republic (ibid.), one-third were studying the Mordvin languages. A comparison of absolute figures allows the assumption that in 2009-10 about half of Erzya and Moksha children in the titular republic were taught their mother tongue either as the native language (including as the language of instruction) or the state language. An increase in the share of pupils learning mother languages may probably be explained, inter alia, by their continued studies against the background of a rapidly declining total number of schoolchildren.

When the regional Law on State Languages was amended in 2010, provisions for studying these languages were altered. The new law mentions only that the republic ensures the conditions for studying and teaching its state languages (RM Law, 12 March 2010). Teaching the state languages is thus no more mandatory under the 
present legislation. Nevertheless, it is recommended that the Mordvin languages and literature are taught as native for four (in secondary) and five hours (in primary education) per week and as a state language for two hours (Methodical recommendations 2009). Those children who are taught the titular language as native, study it not at their choice but by decision of their school. As pointed out above, because of the transition to teaching Mordvin languages as state languages the share of pupils who study them as native languages has dropped by half in recent years.

\section{State and native languages}

Statistics therefore give aggregate figures of state language and native language learners, and therefore the percentage of "titular" children studying their mother tongue cannot be obtained directly. It is more difficult, thus, to evaluate the dynamic development of language teaching as a tool for reproduction of a specific linguistic community. Analysis of the secondary sources allows us to assume that their share in Komi and Mari El has been increasing since the early 1990s and probably now over half the children of titular origin can study their languages either as state or native language. Some further decrease was predetermined by the overall decline in the number of students: within twenty years of the observed period in the Finno-Ugric republics the number students decrease on two occasions.

Taking into account the fact that mother tongue is taught as the native language to a considerable numbers of children in Komi, Mari El and Mordovia, and to all children who study mother languages in Udmurtia and Karelia, it is reasonable to examine separately the two further modes of language teaching: as the native language and as the native language of instruction.

\section{Teaching of native languages in Finno-Ugric republics}

As regards developing the language competence, it is certainly more efficient to teach a language as the native rather than the state language, since the former can be taught to pupils in a larger number up to six hours per week (Federal Core Curriculum, 9 March 2004), although depending on the grade and the republic it is usually taught for three to five hours. Before the reform, native languages were taught within the national-regional and school components of the curriculum. The abrogation of these components caused concern in republics that native language teaching would be dropped entirely. After negotiations and compromises, the initiators of the reform announced that under the new legislation the language can be taught as native in the segment of the main curriculum formed by participants in the education process, that is, by teachers, children and their parents. However, "the difference from the previous legislative norms is that schools must implement the teaching of native languages, including Russian, only at the will and choice of the participants in the education process themselves instead of the regional education agencies" (Artemenko 2010, p. 50).

67 The goal of testing linguistic skills as the product of language learning seemed to have fallen by the wayside within the existing system. One of the reasons for this used to be that mastering "native languages" was not included among graduation requirements (Klementiev 2008, pp. 67-69). Russian used to be the only language of final certification exams in the basic secondary and complete secondary education. After a heated public 
debate the native languages can also become subjects of optional final examinations both after completion of the stages of basic secondary and complete secondary education by decisions of regional authorities (Federal Law, 3 June 2011). Soon after that, the unified regional state exam in the discipline 'state language of the republic' was elaborated in Karelia (RK Law, 3 November 2011), where the education law was amended to enable the native languages to be subjects of the final examinations. In Udmurtia a regulation (7 February 2012) was approved.

\section{Udmurt Republic}

In the Udmurt Republic, too, Udmurt was designated the state language of the republic (along with Russian). Despite this, multilingualism has not been institutionalised as an attribute of the "multinational people" of this republic. Its language policy is directed solely at a set of "peoples" representing distinct linguistic communities. Language planning is hence focused on providing access to learning native languages for all schoolchildren of the titular and other nationalities, irrespective of their will. In legislative and regulatory documents on language policy in this republic the policy objective is defined as "the satisfaction of the need of peoples of the republic" and applied by the regional education ministry as a criterion to evaluate implementation of the language legislation. The sustainability of languages within the respective linguistic communities is both the goal and the criterion of evaluation of language planning and language policy in general.

69 In Udmurtia the department of national education was created in the Ministry of Public Education in 1990 (Vorontsov 2006) and elaborated the first Concept of National Schools (24 January 1991). However, later the department was transformed into just a sector of national education in the Ministry of Education and Science. The republic's Law on Public Education of 1995, including its revised version of 2001, as well as the new Education Law of 2004, established that teaching state languages in all education institutions must comply with the state education standards; the law also avoided establishing compulsory study of the Udmurt language. The republic must therefore only provide support to citizens who want to study its state languages (Article 6, UR Law, 13 January 1996, revised 24 April 2001; UR Law, 16 April 2004). When in 2009 a new regional law on education issues was enacted, it contained no provisions at all on the teaching of state languages (UR Law, 15 December 2009). The Law on State Languages provides the right to study Udmurt only as the native language (UR Law, 6 December 2001).

In Udmurtia, Udmurt was taught in the academic year 1989-90 to 29,278 pupils or arguably $29 \%$ of Udmurt schoolchildren (the data for 1990-91 not available) and in 1994-95, to 34,888 (approx. 42\%). In 2000-01 it was taught as the native language to 33,143 pupils or $41.2 \%$ of Udmurt schoolchildren (UR Concept, 27 January 2000; Shutov 2003, pp. 20-21). The total number of pupils studying Udmurt in 2005-06 was 22,208 (Ministry of Education Dept. Information 2007). In 2008-09 their number fell to 19,315, which was $13 \%$ of all pupils and less than a half of Udmurt schoolchildren (Vorontsov 2006, p. 33, 2009, p. 664; Vorontsov \& Semenov 2010, p. 109; Vasilieva \& Vorontsov 2008, p. 70). As for the academic year 2009-10, by then official sources could only say that Udmurt was taught to $15 \%$ of all schoolchildren in Udmurtia (Ministry of Education Board Decision, 30 June 2010). It is recommended that native Udmurt (Tatar, Mari) languages and literature are taught on average for four hours per week for those 
students who have the language knowledge and three hours for those without the language knowledge (Methodical recommendations 2010; Communication, 19 December 2011). 20,229 students were reported to learn Udmurt in the academic year 2011-12; however, out of this number 17,263 learned it as a mandatory and 2,966 as an optional subject (UR Ministry of Education, 11 April 2012).

71 The number of language learners in urban schools remains very low. In 2009-10 1,773 students or only about one tenth of language learners of the republic studied the language in urban schools. Typically these are normal schools with national classes. As the statistics for the capital city Izhevsk demonstrates, the dynamics of the number of language learners in urban schools more or less coincided with the overall dynamics: 1,799 students in 2000-01, 2,097 in 2004-05, and 1,094 in 2009-10 (Kuzmina 2012; UR Ministry of Education Board Decision, 30 June 2010). However, the proportion of schoolchildren with access to language learning is quite low, given the assumption that more than one third of Udmurt children live in the capital city of Izhevsk, because, according to statistical data, more than a third of the total population lives there, whereas the share of ethnic Udmurts in the population of Izhevsk more or less reflects their share in the total population of the republic.

\section{Republic of Karelia}

Despite the difference in the status of titular languages (Udmurt as the state language of Udmurtia, and Karelian as the native language in Karelia), in both republics they are studied as the native language. In the Republic of Karelia, the titular Karelian language has not been established as the state language and therefore is taught only as the native language (Article 5, RK Law, 19 March 2004) in the form of either Karelian proper or the Olonets dialect. There were plans to create a department of national education in the Ministry of Public Education of the Republic of Karelia, but the attempts failed, and only one of the vice Ministers was responsible for the issues in 1990-94 (Klementiev 2008). Nevertheless, "the teaching of the native languages of the republic was declared mandatory in education institutions located in areas of dense Karelian and Veps population in the territory of the republic" (cited: Klementiev 2010, p. 27). In practice, language teaching provided in the schools of only some areas implies that the share of native language learners is somewhat lower than the general share of language learners marked below.

Only 301 or about $3.4 \%$ of pupils of Karelian origin were taught their mother language in the academic year 1989-90 and 571 in 1990-91 or about 4.9\% (Kovalyova 2012, p. 309; Klementiev 2006c). In 1995-96 their number increased to 2,522 or about $20.6 \%$. The top academic year for teaching Karelian in varying amounts was 2001-02, when it was taught to 2,596 or about $17.6 \%$ of schoolchildren of Karelian origin. In 2005-06 the Karelian language was taught to 1,751 pupils; according to expert estimates, this made up around 27.2\% of schoolchildren of Karelian origin (Klementiev 2006b). By 2009-10 their number dropped to 1,657 or about $25 \%$ (Klementiev 2010, pp. 302-303; Kovalyova 2012, pp. 313-314). Of them, less than $40 \%$ were taught Karelian (in eight schools total) during a whole education stage, usually for two hours per week (in grades 1 to 4,1 to 8 or 9, or 10-11). In other schools Karelian was taught to individual classes for less than four years. Among the schools, only in the Petrozavodsk Finno-Ugric School was the language taught for all eleven grades. Notably, the share of students learning the language in urban and rural schools is alike. Further, nearly one-sixth of pupils studied 
their native language extracurricularly (Klementiev 2007, p. 90). Another problem is that the language is taught only for one or two hours per week in the first grade and two or three hours in grades $2-4$ (Communications, 8 June 2011).

\section{Native language of instruction in the Finno-Ugric and neighbouring Turkic republics}

74 At the time of the collapse of the USSR, among the Finno-Ugric languages only in Mari $\mathrm{El}$ and Mordovia did native language still serve as the medium of instruction in primary rural schools, the other languages being taught only as subjects. For development of language competence and bilingualism in schoolchildren, instruction in the native language is most preferable. In the early 1990 s the idea about the reintroduction of the native language of instruction, at least to some (rural) children, was discussed, for example, in Komi. However, this idea, let alone the idea of compulsory native language instruction, was seen as unrealistic due both to objective financial obstacles and the negative attitudes of the generation of parents raised in the 1970-1980s in the Russian language and unfamiliar with native-language school.

The situation did not change in this respect in the post-Soviet period: among the regions considered, instruction in the native language at elementary school has only remained in a reduced numbers in the republics of Mari El and Mordovia. In the academic year 1990-91, at elementary school in Mari El, there were 8,706 pupils instructed in Mari (7,162 in Meadow Mari and 1,544 in Hill Mari), and around 9,500 in 1994-95 (Strogalshchikova 2008, p. 146, Table). In 2000-01, Mari pupils instructed in their native language numbered 6,316 (5,194 in Meadow Mari and 1,122 in Hill Mari) (Sharov 2002). In the academic year 2004-05 their absolute number plummeted to 752 (National Education 2005, pp. 36-38), and then to 273 in 2007-08 (Tishkov et al. 2009, Table 10). It is interesting to note that the official statistics of 2005, probably seeking to soften the contrast, marked down the number of pupils instructed in their native language in 2000-01 to 1210 (IHF Report 2007, p. 70). In any event, education in the native language in Mari El has virtually vanished.

In Mordovia, the number of pupils instructed in Erzya and Moksha was 4,719 in the academic year 1990-91, and around 5,900 in 1994-95 (Strogalshchikova 2008, p. 146, Table). According to the RM Ministry of Education, this figure was 5366 in 1999-2000, 2,548 in 2004-05 (National Education 2005, p. 20), and 1,680 at the beginning of the academic year 2009-10 (Network of Schools 2010). Based on the 1999-2000 official republican data, O. Podlesnykh argues that almost 30\% of Erzya and Moksha schoolchildren had the native language of instruction (2002). She based her calculation on the share of Erzya and Moksha schoolchildren (21032) among all republic's schoolchildren (113,323), which is almost a half less than the share of Erzya and Moksha in the total population of the republic (31.9\%). According to the 2007-08 official republican data, only Mordvin children compose only $15.6 \%$ of all schoolchildren in the republic. This is improbably in the light of the fact that the share of the "titular" population increased between 2002 and 2010 from $31.9 \%$ up to $40 \%$. The information on the share of students learning the Mordvin languages is rarely provided in Mordovia. The other researchers assume that the share of titular students reflects the share of the titular population in the total population of the republic (Martynenko 2011a, p. 183). 
77 Russia-wide surveys sometimes tend to create a different impression, for example by indicating instruction in Mari and Udmurt at senior school (Kuzmin \& Artemenko 2010, p. 47) but leaving unmentioned that this is so in the republics of Bashkortostan and Tatarstan only. Udmurt and Mari are used in Bashkortostan for instruction respectively up to the 5th and 9th grades, and in Tatarstan up to the 11th grade. In these republics, respectively, instruction in Mari at both elementary and senior school in the academic year 1990-91 was carried out for 4,305 and 236 pupils, and in Udmurt for 699 and 757 pupils; in Tatarstan in the same year there were 40 pupils instructed in the Erzya language (Strogalshchikova 2008, p. 147). In Bashkortostan, in the 1999-2000 academic year 512 or $11.2 \%$ Udmurt and 5,337 or $25.2 \%$ Mari schoolchildren learned their mother tongue. In the 2003-04 academic year the numbers were 344 or $9 \%$ Udmurt and 4233 or 23.5\% Mari schoolchildren (Garipov et al. 2006, pp. 12-14). In the 2009-10 academic year the numbers were 248 or $8.6 \%$ Udmurt and 2809 or $20.8 \%$ Mari schoolchildren (RB Concept of the Development, 31 December 2009). In the 2007-08 academic year there were 347 and 218 pupils in Tatarstan instructed respectively in Udmurt and Mari (Tishkov et al. 2009, Table 10). For a comparison, in Tatarstan $26.6 \%$ Tatar schoolchildren had the native language of instruction in 1990-91, 43\% in 1995-96, $48 \%$ in $2000-01,51.9 \%$ in $2005-06$ and $46.13 \%$ in 2010-11 (Data on National Education 2004, 2007; Gataullina 2001, p. 61; Gabdrakhmanova 2006; Iazyki v sisteme obrazovaniia 2011, pp. 145-146, Table 7); In Bashkortostan about 31\% of Bashkir schoolchildren had the native language of instruction in 1992-93,39.1\% in 2005-06, about $39.7 \%$ in 2000-01 and 37.8\% in 2009-10 (Safin 1994, 1997; Gabdrafikov 2006a, 2006b; Gabdulgafarova 2006; Garipov et al. 2006; Rakhmatullina 2006; Gorbachov 2011 (see Tables 4 and 5 below).

The initiators of amendments to the Education Law insist that, as in the case of taking a decision on whether or not to teach native languages at school, the participants in the education process must decide on the language of instruction (Kuzmin \& Artemenko 2010, p. 46). This arrangement, however, was already established under the 1998 amendment to the Language Law (Federal Law, 24 July 1998, Article 8). Since the beginning of a new education reform (Federal Law, 1 December 2007) the federal authorities enforced voluntary choice of the language(s) of instruction and voluntary study of native languages by amendments to the Education Law (see Zamyatin 2012a). The main point in the latest legislative amendments in this regard is that, proceeding from freedom of choice of languages of instruction established under the Russian Constitution and the Language Law, it was now forbidden for the ministries of education of the republics to interfere with selection of languages of instruction at schools.

\section{Teaching of native languages in the non-titular regions}

As a result of arbitrary administrative border changes and migration policies, significant parts of ethnic groups live outside the borders of their titular territorial units. Today, more than half Mordvins and almost half Mari, one in four Karelians, and a significant number of Komi and Udmurts live outside their titular republics, where the language shift is more extensive (see Table 1 above). In comparison to previous censuses, the share of those living within the borders of their titular republics has increased for all groups and the share of those living outside decreased. This might be, among other things, a consequence of the language education policies of different regions. That is why it is also important to study the policies of non-titular regions, 
particularly in regard of the Mari and Mordvin languages. In republics the statistics distinguish the data on the teaching of titular native languages from the data on the teaching of other native (non-Russian) languages: Nenets in Komi, Udmurt, Tatar and Chuvash in Mari El, Tatar in Mordovia, Tatar, Chuvash and Mari in Udmurtia, Veps and Finnish in Karelia, Tatar and Mordvin (Erzya) in Chuvashia. Significant groups of Mari, Mordvins and Udmurts traditionally reside in neighbouring Turkic republics (see Table 2).

Table 2. Some non-Russian populations in Bashkortostan, Tatarstan and Chuvashia (2010)

\begin{tabular}{|c|c|c|c|c|c|c|}
\hline Total & Bashkir & Tatar & Chuvash & Mari & Udmurt & Mordvin \\
\hline \multicolumn{7}{|c|}{ Republic of Bashkortostan } \\
\hline 4,072292 & 1,172287 & 1,009295 & 107,450 & 103,658 & 21,477 & 20,300 \\
\hline $100 \%$ & $29.5 \%$ & $25.4 \%$ & $2.7 \%$ & $2.6 \%$ & $0.5 \%$ & $0.5 \%$ \\
\hline \multicolumn{7}{|c|}{ Republic of Tatarstan } \\
\hline 3,786488 & 13,726 & 2,012571 & 116,252 & 18,848 & 23,454 & 19,156 \\
\hline $100 \%$ & $0.4 \%$ & $53.2 \%$ & $3.1 \%$ & $0.5 \%$ & $0.6 \%$ & $0.5 \%$ \\
\hline \multicolumn{7}{|c|}{ Republic of Chuvashia } \\
\hline 1,251599 & & 34,214 & 814,750 & 3,648 & & 13,014 \\
\hline $100 \%$ & & $2.8 \%$ & $67.7 \%$ & $0.3 \%$ & & $1.1 \%$ \\
\hline
\end{tabular}

SOURCES: NATSIONALNYI SOSTAV, 2010.

The sociolinguistic situations of these republics differ from that of the Finno-Ugric ones, inter alia, because non-Russians are in the majority. As a result of the regional language revival, the number of native language learners among these nationalities had somewhat increased in the 1990s and stabilised around the turn of millennium (Safin 1994, 1997; for the data see Tables 4 and 5 below). It is reported that in Bashkortostan, in the 1999-2000 academic year 2,779 or $60.8 \%$ of Udmurt, 12,335 or $58.3 \%$ of Mari, 284 or $8.6 \%$ of Mordovian schoolchildren learned their mother tongue. The respective figures were 2,485 or $64.7 \%$ Udmurt, 11,152 or $61.8 \%$ Mari and 391 or $16.4 \%$ Mordvin schoolchildren for the 2003-04 academic year (Garipov et al. 2006, pp. 12-14). In the academic year 2009-10 the mother tongue was taught to 1,824 or $63.3 \%$ Udmurt, 9,130 or $67.34 \%$ Mari and 410 or $26.9 \%$ of Mordvin schoolchildren in Bashkortostan (RB Concept of the Development, 31 December 2009). In Tatarstan, 2,514 or $71 \%$ schoolchildren were taught their native Udmurt, 1,238 or $49 \%$ Mari and 188 or $8 \%$ Mordvin languages in 1999-2000. The corresponding numbers for the academic year 2003-04 are 2,356 or $70 \%$ Udmurt, 1,268 or $49 \%$ Mari and 186 or $8 \%$ Mordvin languages. In the academic year 2007-08 the mother tongue was taught to 1488 or $62.3 \%$ Udmurt, 683 or $48 \%$ Mari and 118 or $8 \%$ Mordvin schoolchildren in Tatarstan (Gataullina 2001; Gabdrakhmanova 2006, p.46). In contrast, practically all schoolchildren of titular 
nationality in Bashkortostan and Tatarstan today have access to native language learning either as the medium of instruction or as a subject (see Tables 4 and 5).

In addition, outside the titular republic, in the academic year 2007-08, Udmurt was taught to 122 pupils in Mari El, 61 pupils in the Kirov Region as an extracurricular subject, and 84 and 35 children in the Perm Territory and Sverdlovsk Region, respectively (UR Ministry of Education Information 2007). In the same period the Mari language was also taught in Udmurtia, to 237 children in the Kirov Region, a few schoolchildren in the Nizhniy Novgorod Region, in Perm Territory, and 93 pupils in the Sverdlovsk Region.

82 The Mordvin languages are studied as a separate subject, usually with modest coverage of pupils and mostly as an extracurricular course. Outside the titular republic they were taught to 7,248 students in 1999-2000 and to 9,911 in 2004-05 (National Education 2005, p. 20). According to the RM Ministry of Education data, in 2007-08 they were taught to 4,541 students, including 729 in the Republics Bashkortostan, 292 in Chuvashia and 380 in Tatarstan, but also in Orenburg, Ulyanovsk, Saratov, Samara, Penza and Nizhniy-Novgorod Regions (On Learning the Mordvin Languages 2008, p. 14). Notably, the Tatarstan and Bashkortostan Ministries of Education give smaller numbers (see above). In the traditional areas of settlement of the Mordvin diaspora, there is practically no teaching of the Mordvin languages in the Ryazan, Tambov and Chelyabinsk Regions.

Outside the titular republic, Komi is taught to a small number schoolchildren in the Nenets AD (25 pupils in 2008), the Yamal-Nenets AD (95 pupils in 2008) and in the Murmansk Region (in two schools in Lovozero village), although in these regions it does not have the status of a "language of a small numbered indigenous people" (Materials 2009, pp. 67-68). Karelian is taught to several hundred pupils at some schools in the Tver Region (16 schools in 2002) as an optional subject, except for one school where it remains compulsory (Tverskie vedomosti 2010). In the Republic of Karelia, apart from Karelian, Veps (discussed in the next section) and Finnish are taught as well. In the academic year 1989-90 there were 5,502 schoolchildren studying Finnish, 13,422 in 1995-96, 10,340 in 2001-02, and 6,129 in 2005-06 (Klementiev 2006a, Table 1; 2006d). In 2009-10 Finnish was taught to 4,492 pupils of whom ethnic Finns were a small share (Vasilieva 2010, p. 170). Pupils who learn Finnish outnumber those of Finnish origin in the republic several times: many children of other nationalities want to study this language.

84 In Saint Petersburg, Finnish is taught in five schools as a foreign language (Russia's Second Report 2005, p. 31). However, in the academic year 2009-10 only two of them had a complete course of Finnish included in the main lesson grid. There are eleven schools in Saint Petersburg where Finnish is taught extracurricularly, and in the Leningrad Region three schools located in Gatchina, Vyborg and Koltushi (Kirjanen 2010, p. 21). There is also one Finnish and one Estonian Sunday school in Saint Petersburg (National Institutions 2011). Estonian is taught as a foreign language in the Pskov Region; in 2008-09 it was studied by 131 pupils at Secondary School No. 2 in the town of Pechory (until recently, they had Estonian as the language of instruction). The last school in Russia with instruction in Estonian, located in Verkhniy Suetuk village, Krasnoyarsk Territory, was closed in 2008. The only school now to study Estonian in that area, at least in the lower grades and extracurricularly, is in the Khaidak village (19 pupils in the academic year 2007-08; see Arefiev 2010). 
The Komi-Permyak Autonomous District was at the time of the collapse of the Soviet Union the only Finno-Ugric region in Russia where the titular people prevailed (59.0\%). In 1990-91 the Komi-Permyak language was taught to 6,204 pupils, in 1995-96 to 7,070 pupils or $25.7 \%$ of the total number of schoolchildren, and in 2001 to 5,619 pupils. Remarkably, the District's Education Law of 2005 contained no provisions on language issues except for a requirement of non-discrimination on the grounds of language (KPAD Law, 17 March 2005). It is not a wonder then, that after the abolition of the autonomous district in 2005, the situation in language teaching has deteriorated. Education is organised according to the Education Law of Perm Territory (12 March 2010). In 2005-06 the number of language learners plummeted to 3,948 or $23.7 \%$ of the total number of schoolchildren (Chernykh 2010, pp. 67-68). In 2009-10, the number of pupils who were taught Komi-Permyak fell to 2,444 students or $17.8 \%$ of the total number of schoolchildren, which is officially explained as the schools' free choice to refuse language teaching (Komi-Permyak District Head Report 2010). In the current year, first classes of native language were opened in Kudymkar. Taking the share of Komi-Permyaks among the population of the district and assuming that the language has been taught, basically, to pupils of the titular nationality, it becomes clear that only about one-third of these pupils are taught their mother tongue. Since the KomiPermyaks constitute the majority in the area of the former district, this estimation is more accurate than the rather rough estimations for other regions.

\section{Teaching of the native languages of indigenous small numbered peoples}

86 Unlike the children of the nationalities who have their titular republics, most indigenous children typically lack knowledge of their language and have to learn it as a foreign language (Kazakevitch 2002, p. 9). As the initiators of reform themselves admit (Artemenko 2009, p. 17), the amendments to the federal Education Law have negatively affected the teaching of the languages of indigenous peoples as well as other small numbered peoples, including due to the lack interest in these languages on behalf of teachers and parents. This is especially true since among the indigenous language learners in the North often up to a half are non-indigenous children.

The Baltic-Finnic (Veps and Saami), Ugric (Khanty, Mansi) and Samoyed languages (Nenets, Enets, Nganasan, Selkup) of indigenous small numbered peoples are taught as separate subjects only. Their institutional position in education differs from that of the other languages in Russia in that in addition to regular schools, some special types of schools can be organised such as boarding schools, nomadic schools and some other types. Among them, Nenets, Khanty, Mansi are established as the 'official languages' the titular autonomous districts. None of these languages, including titular languages in autonomous districts, are applied as languages of instruction (Likhanova 2008). In some senior school Nenets, Khanty and Mansi are taught mostly as optional subjects; the teaching of other languages is usually restricted to primary school (Obrazovanie 2005 , p. 230). The most satisfactory situation among indigenous languages is in teaching Veps in the Republic of Karelia. In the academic year 1989-90 there were only 59 pupils studying Veps. In 2001-02 it was taught as a subject to 273 pupils or about $80 \%$ of Veps schoolchildren in the republic (official data, cited from Kazakevitch 2002, 
p. 31). In 2005-06 their number rose to 326 (Klementiev 2006a, p. 191). The Veps language is also taught at some schools in the Podporozhsky district, Leningrad Region.

The languages of indigenous small numbered peoples are systematically taught, above all, in their respective autonomous districts. As in the republics, teaching mother tongues such as Nenets and Khanty grew in the 1990s and reached its maximum in the academic year 2000-01 when all over Russia the Khanty language was taught to 2379 , Mansi to 741, Nenets to 5 202, Nganasan to 137 and Selkup to 171 pupils (Orbazovanie 2005 , p. 229). The federal numbers for the same year differ somewhat: the Khanty language was taught to 2,526, Mansi to 1,057, Nenets to 5,484, Nganasan to 491 and Selkup to 213 pupils (Kuzmin et al. 2005). Federal data for the academic year 2005-06 give the rounded number of 2,380 pupils who were taught Khanty $(1,166$ in the YNAD and 1,213 in KMAD). In the KMAD, the Mansi language was taught to 741 Mansi pupils in 2005-06; it was also reported that in 2004-05 among the 1,042 schoolchildren in the district who were taught the Mansi language, 783 were of Mansi origin (Lalaieva 2005, Education of Indigenous 2005). The Nenets language was taught to 5,202 pupils (854 in the NAD, 3,828 in the YNAD, 74 in the KMAD, and 446 in the Taimyr municipality of the Krasnoyarsk Territory. The Nganasan language was taught to 137 and the Enets language to 27 pupils in the former Taimyr Autonomous District - today municipality, Krasnoyarsk Territory. The Selkup language was taught to 48 pupils in the YNAD and to 22 pupils in the Tomsk Region (Tishkov et al. 2009, Table 9).

Among the autonomous districts that still exist, the example of establishing a regional legislative framework to ensure protection of languages has been set by the KhantyMansi AD. In 2001 the district adopted the Law on Native Indigenous Languages (KMAD Law, 4 December 2001; Article 3 and 4). This law covers the Khanty, Mansi and Nenets languages. In some aspects it even exceeds the language laws of some republics. For example, the law is to be implemented through local purpose-oriented programs that may include, among other measures, the introduction of a system of continuous education in native languages (Article 2-4). A respective programme was approved but it did not contain measures to support these languages (KMAD Target Programme, 31 October 2007). The amendments of 2008 to the District's Education Law made it the competence of the district authorities to support the teaching of native languages in education institution authorities (KMAD Law, 11 November 2005, Article 3-1). The national-regional component and basic study plan were approved, assigning three hours per week for native language and literature teaching in primary school (KMAD Government Decree, 31 August 2005; KMAD Education Department Order, 14 September 2005). The district department of education reported in 2008 that mother languages were taught to about $30 \%$ of children of indigenous descent. In the traditional areas of settlement of those peoples, 4,637 children were studying in schools that had programmes of teaching native languages and culture; 2,610 of these children were of indigenous descent (Implementation 2008). In the 2009-10 academic year 2,826 students of indigenous descent learned their native language as a subject or $55.2 \%$ in the KMAD; whereby the native language and literature is taught in primary and basic secondary school for two hours per week (Spodina 2011, p. 227).

In the Yamal-Nenets AD, the District's Education Law of 2,000 establishes that in the areas of compact settlement of indigenous small numbered peoples teaching of their languages must be conducted (YNAD Law, 31 January 2000, Article 4). The district has also a language law that was passed as late as in 2010, probably under the indirect 
influence of the freshly adopted UN Declaration of Rights of Indigenous Peoples (YNAD Law, 5 April 2010, Articles 3 and 4). This law covers the Nenets, Khanty and Selkup languages, and is specific in that it establishes a very vague regulation of education issues. The only provision enacts the introduction of a system of continuous training of native languages; it was borrowed from the respective KMAD law (Article 5).

Nevertheless, in the academic year 1999-2000 there were 5,457 schoolchildren in the district studying their mother languages: Nenets was taught to 3,930, Khanty to 1,191, Komi to 178, and Selkup to 158 pupils (Entsiklopediia 2003, p. 279). It was reported that in 2004-05 mother languages were taught as separate subjects to 3,971 Nenets, 1,103 Khanty and 136 Mansi pupils (YNAD Law, 27 June 2006). A district target programme carried out in the period of 2008-11, included among the indicators of its efficiency an increase in the share of children of indigenous descent studying their native language as a subject. According to federal data, in 2007-08 Nenets was taught to 4,074, Khanty to 949, and Selkup to 131 children in the district (Materials 2009, pp. 67-68). The district data for 2008-09 give the numbers of pupils who were taught their native language as a subject as 4377 for Nenets, 1,192 for Khanty, 157 for Selkup, and 32 for Komi. Altogether they made up $60.7 \%$ of all schoolchildren belonging to indigenous small numbered peoples (YNAD Education Department Information 2009). According to the data for the same year from another source, the number of indigenous children learning their native languages was 4,965 students or 53.4\% (YNAD Indigenous Peoples Department Report 2009). In 2010-11 their total number fell to 3,959 or $42 \%$. Of them, Nenets was taught to 3,157 , Khanty to 769 , and Selkup to 33 schoolchildren (Territoriia 2010).

In the Nenets AD, the District's Education Law of 1998 establishes that "the basic language of instruction in the district and the language of interethnic communication is Russian". The governing body of an education institution has nevertheless the right to decide in favour of instruction in Nenets (NAD Law, 15 January 1998, Articles 1, 16). The Federal Supervision Service for Education and Science has reported that in 2008 the district had four functioning schools with instruction in Nenets, with altogether 821 pupils (Materials 2009, pp. 67-68). The RF Ministry of Education, however, does not confirm the use of Nenets for instruction (Tishkov et al. 2009, Table 9). According to the Association of Nenets People "Iasavei", in the academic year 2009-10 the Nenets language was taught to 570 and in 2010-11 to 676 pupils, which is probably more than half of Nenets schoolchildren in the district (Learning the Nenets Language 2010). The District's Education Law also provided for the establishment of so-called "mobile schools" for primary education of children of families leading a nomadic life; this provision was later revoked. A district programme for the development of education provided measures to support the Nenets and Komi languages (NAD Target Programme, 21 April 2006). The district has no language law.

In recent years, according to a 2008 report of the Federal Service for Supervision in Education and Science, some regions have established pre-school and general education institutions teaching native languages and cultures of indigenous small numbered peoples, including as school subjects. There are 37 such schools in the YNAD and 11 in the NAD (Materials 2009, pp.67-68). Boarding schools still retain their position in the education system. Meanwhile, under the provision of the federal Education Law on development of home schooling, mobile schools functioning at cattle camps are also supported. 
Taking the general tendency of reduction in the numbers of children, the situation in teaching Nenets, Khanty and Mansi can be considered relatively stable. It is important to note that Nenets are the most numerous people (44,500 strong, according to the 2010 census) among those recognised as small numbered indigenous peoples under Russian legislation. They are the titular nationality in the YNAD and NAD. However, the situation in language teaching varies from district to district, and even more in different regions and territories. In the Tyumen Region, neither Khanty nor Mansi are taught even as a subject (Materials 2009, p. 94). In the Murmansk Region, the Saami language is taught only in lower grades. It was taught to 36 pupils in 1998-99, 14 pupils in 2001-02 and 19 pupils in 2005-06 (Strogalshchikova 2008, p. 150; Kazakevitch 2002, p. 32; Tishkov et al. 2009, Table 9). The situations in teaching languages of groups who number a few hundred or dozen people vary even more strikingly. The Votic and Izhorian languages in the Leningrad Region are examples of languages not used in education.

\section{Results and discussion: access to native Finno-Ugric language learning}

The combined data illustrate the processes that were going on in language education of the Finno-Ugric republics (see Table 3) and Tatarstan and Bashkortostan (see Tables 4 and 5). Generalised preliminary results in Table 3 for the years 1990-91, 2000-01 and 2009-10 were presented first in Zamyatin (2012b).

Table 3. Teaching of the titular languages in the Finno-Ugric Republics

\begin{tabular}{|l|l|l|l|l|l|}
\hline Republic & Komi & Mari El & Mordovia & Udmurtia & Karelia \\
\hline Year & $\mathbf{1 9 9 0 / 1 9 9 1}$ & $\mathbf{1 9 9 0 / 1 9 9 1}$ & $\mathbf{1 9 9 0 / 1 9 9 1}$ & $\mathbf{1 9 8 9 / 1 9 9 0}$ & $\mathbf{1 9 9 0 / 1 9 9 1}$ \\
\hline Stud. total & 201,000 & 116,000 & 132,000 & 247,400 & 117,000 \\
\hline Ethnic stud. $^{\mathrm{b}}$ & $\sim 46,800$ & $\sim 50,200$ & $\sim 42,900$ & $\sim 76,600$ & $\sim 11,700$ \\
\hline Instruction $^{\mathrm{c}}$ & 0 & 8,706 & 4,719 & 0 & 0 \\
\hline Native lang. & 15,890 & 27,700 & 16,576 & 29,278 & 571 \\
\hline Native share & $\sim 34 \%$ & $\sim 55.2 \%$ & $\sim 38.6 \%$ & $29 \%$ & $\sim 4.9 \%$ \\
\hline State lang. ${ }^{\mathrm{e}}$ & 3483 & - & - & - & - \\
\hline State share & $\sim 6 \%$ & - & - & - & - \\
\hline Ethnic share & $\sim 40 \%$ & $\sim 55.2 \%$ & $\sim 38.6 \%$ & $29 \%$ & $\sim 4.9 \%$ \\
\hline Share totalg & $10.5 \%$ & $\sim 31.5 \%$ & $\sim 16 \%$ & $\sim 12 \%$ & $\sim 0.5 \%$ \\
\hline Year $^{\mathrm{f}}$ & $\mathbf{1 9 9 4 / 1 9 9 5}$ & $\mathbf{1 9 9 5 / 1 9 9 6}$ & $\mathbf{1 9 9 4 / 1 9 9 5}$ & $\mathbf{1 9 9 4 / 1 9 9 5}$ & $\mathbf{1 9 9 5 / 1 9 9 6}$ \\
\hline Stud. total & 195,000 & 131,360 & 141,000 & 268,200 & 122,000 \\
\hline
\end{tabular}




\begin{tabular}{|l|l|l|l|l|l|}
\hline Ethnic stud. & $\sim 45,400$ & $\sim 56,700$ & $\sim 45,800$ & $\sim 82,800$ & $\sim 12,200$ \\
\hline Instruction & 0 & 9500 & 5900 & 0 & 0 \\
\hline Native lang. & 17,568 & 29,730 & 15,540 & 34,888 & 2,522 \\
\hline Native share & $\sim 38.7 \%$ & $\sim 52.4 \%$ & $\sim 34 \%$ & $42 \%$ & $\sim 20.6 \%$ \\
\hline State lang. & 10,797 & 21,256 & - & - & - \\
\hline State share & $\sim 6.3 \%$ & $\sim 16.6 \%$ & - & - & - \\
\hline Ethnic share & $\sim 45 \%$ & $69 \%$ & $\sim 34 \%$ & $42 \%$ & $\sim 20.6 \%$ \\
\hline Share in total & $16.6 \%$ & $38.8 \%$ & $\sim 11 \%$ & $\sim 13 \%$ & $\sim 2 \%$ \\
\hline
\end{tabular}

a The total numbers of students in republics are given for the years 1990-91, 1995-96, 2000-01, 2005-06, 2010-11 from Rossiiskii statisticheskii iezhegodnik 2011, pp. 216-217, Table 7.14.

b The symbol ' $\sim$ ' marks estimations in the numbers of student of titular nationality that are calculated by applying the share of the titular group in the total population of republic according to the population censuses (see Table 1) to the total number of student in the republic: the 1989 census data are applied to the estimations in the academic years 1989-90 (1990-91) and 1994-95 (1995-96), the 2002 census data are applied to the estimations in the academic years 1999-2000 (2000-01) and 2004-05 (2005-06), the 2010 census data are applied to the estimations in the academic years 2009-10 (2010-11). In reality the share among minority younger generations tends to be lower than presented as a consequence of assimilation. c HERE AND IN THE FOLLOWINg TABLES 4 AND 5 THE NUMBER OF STUDENTS LEARNINg THE NATIVE
LANGUAgE AS A SUBJECT INCLUDES THE NUMBER OF STUDENTS RECEIVINg NATIVE LANGUAgE INSTRUCTION. ACCORDINGLY, THE SHARE OF NATIVE LANGUAgE LEARNERS INCLUDES BOTH CATEgORIES.

${ }^{d}$ According to calculations, the share should be $38 \%$. The given absolute number and share is according to K. Kulikov ('Bolshie problem "malogo" naroda'. Nauka Urala, 11 August 1988); R. Taagepera gives the number of Udmurt children learning their native language in 1989 as 26,100 (1999, p. 287); K. Ponomariov as 20,000 or 20\% ('Gosudarstvennyi naravne s russkim'. Udmurtskaia Pravda, 20 September 1990); yet another estimate is 12000 students (Kazimov et al. 2008, p. 56).

\begin{tabular}{|l|l|l|l|l|l|}
\hline Year & $1999 / 2000$ & $2000 / 2001$ & $1999 / 2000$ & $2000 / 2001$ & $2000 / 2001$ \\
\hline Stud. total & 169,000 & 120,400 & 129,000 & 246,000 & 109,000 \\
\hline Ethnic stud. & $\sim 42600$ & $\sim 51500$ & $\sim 41150$ & $\sim 72000$ & $\sim 10000$ \\
\hline Instruction & 0 & $6,316^{\mathrm{h}}$ & 3,597 & 0 & 0 \\
\hline Native lang. & 16,926 & 25,974 & 16,136 & 33,143 & 2,149 \\
\hline Native share & $\sim 39.7 \%$ & $\sim 50.4 \%$ & $\sim 39.2 \%$ & $41.2 \%$ & $17.6 \%$ \\
\hline State lang. & 21,224 & 46,559 & 3,191 & - & - \\
\hline State share & $\sim 12.4 \%$ & $\sim 9.9 \%$ & $\sim 2.5 \%$ & - & - \\
\hline Ethnic share & $\sim 52.1 \%$ & $81.9 \%$ & $\sim 41.7 \%$ & $41.2 \%$ & $17.6 \%$ \\
\hline Share in total & $20.2 \%$ & $60.3 \%$ & $\sim 15 \%$ & $\sim 14.5 \%$ & $\sim 2 \%$ \\
\hline
\end{tabular}




\begin{tabular}{|l|l|l|l|l|l|}
\hline Year & $2004 / 2005$ & $2004 / 2005$ & $2004 / 2005$ & $2005 / 2006$ & $2005 / 2006$ \\
\hline Stud. total & 119,000 & 82,000 & 89,000 & 173,000 & 75,000 \\
\hline Ethnic stud. & $\sim 30,000$ & $\sim 35,200$ & $\sim 28,400$ & $\sim 50,700$ & 6,434 \\
\hline Instruction & 0 & 752 & 2,548 & 0 & 0 \\
\hline Native lang. & $\sim 12,000$ & 18,692 & 14,998 & 22,208 & 1,751 \\
\hline Native share & $\sim 40 \%$ & $\sim 53.1 \%$ & $\sim 52.8 \%$ & $\sim 43.8 \%$ & $27.2 \%$ \\
\hline State lang. & $\sim 28,000$ & 25,414 & 8,626 & - & - \\
\hline State share & $\sim 23 \%$ & $\sim 30.9 \%$ & $\sim 9.2 \%$ & - & - \\
\hline Ethnic share & $\sim 63 \%$ & $\sim 84 \%$ & $\sim 62 \%$ & $\sim 43.8 \%$ & $27.2 \%$ \\
\hline Share in total & $32 \%$ & $\sim 53.8 \%$ & $\sim 26.5 \%$ & $\sim 14 \%$ & $\sim 2.33 \%$ \\
\hline
\end{tabular}

\begin{tabular}{|l|l|l|l|l|l|}
\hline Year & $2009 / 2010$ & $2009 / 2010$ & $2009 / 2010$ & $2008 / 2009$ & $2009 / 2010$ \\
\hline Stud. total & 97,000 & 66,100 & 69,750 & 154,000 & 63,000 \\
\hline Ethnic stud. & $\sim 23,000$ & $\sim 29,000$ & $\sim 27,600$ & $\sim 43,100$ & $\sim 4,660$ \\
\hline Instruction & 0 & $273^{\mathrm{h}}$ & 1,689 & 0 & 0 \\
\hline Native lang. & 6,200 & 11616 & 7,670 & 19315 & 1,657 \\
\hline Native share & $\sim 27 \%$ & $\sim 40 \%$ & $\sim 27.8 \%$ & $\sim 44.8 \%$ & $\sim 25 \%$ \\
\hline State lang. & 27,800 & 29,304 & 15,493 & - & - \\
\hline State share & $\sim 28.6 \%$ & $\sim 44.3 \%$ & $\sim 22.4 \%$ & - & - \\
\hline Ethnic share & $\sim 55.6 \%$ & $\sim 84.3 \%$ & $\sim 50.2 \%$ & $\sim 44.8 \%$ & $\sim 25 \%$ \\
\hline
\end{tabular}




\begin{tabular}{|l|l|l|l|l|l|}
\hline Share in total & $35 \%$ & $62 \%$ & $\sim 33.5 \%$ & $13 \%$ & $\sim 2.5 \%$ \\
\hline
\end{tabular}

E BOTH NON-NATIVE (RUSSIAN-SPEAKINg AND OTHERS) AND NATIVE STUDENTS LEARN THE TITULAR STATE LANgUAgE IN SOME REPUBLICS. IT IS ASSUMED THAT AMONg THE STATE LANgUAgE LEARNERS, NATIVE STUDENTS COMPOSE A SHARE THAT REFLECTS THE SHARE OF THE TITULAR gROUP IN THE TOTAL POPULATION ACCORDING TO THE POPULATION CENSUSES; HOWEVER THESE CALCULATIONS CANNOT BE VERIfIED ON THE BASIS OF OFfICIAL STATISTICS BECAUSE IT DOES NOT DISTINgUISH THE ETHNICITY OF STATE LANGUAgE LEARNERS.

F THE SYMBOL ' ' MARKS ESTIMATIONS OF THE SHARE OF SCHOOLCHILDREN OF TITULAR NATIONALITY LEARNINg THEIR LANgUAgE BOTH AS NATIVE AND STATE LANgUAgES. WHEN AVAILABLE, OFfICIAL NUMBERS ARE GIVEN WITHOUT A SYMBOL; IN THAT CASE ESTIMATIONS ARE GIVEN IN BRACKETS ONLY, IF THEY DIFFER SIgNIfICANTLY FROM OFfICIAL DATA. THE DISCREPANCY IN THE CASE OF KARELIA COULD BE EXPLAINED BY A LOWER SHARE OF KARELIAN CHILDREN THAN THEIR OVERALL SHARE IN THE TOTAL POPULATION OF THE REPUBLIC DUE TO THE DEFORMATION OF THE AgE-SEX gRAPH.

$g$ THE SYMBOL ' $\sim$ ' MARKS ESTIMATIONS OF THE SHARE OF STUDENTS LEARNINg THE TITULAR LANgUAgE (BOTH AS NATIVE AND STATE LANgUAgE) IN THE TOTAL NUMBER OF STUDENTS IN REPUBLIC; WITHOUT A SYMBOL ARE OFfICIAL NUMBERS.

H FEDERAL DATA; ACCORDINg TO THE OFfICIAL REgIONAL DATA THE NUMBER OF LEARNERS WAS 1,210 STUDENTS - ARgUABLY, THE LATTER NUMBER IS A FALSE DATUM PRODUCED TO CONCEAL A VIRTUAL ELIMINATION OF NATIVE LANGUAgE INSTRUCTION STARTING IN THE YEAR 2001 (COLLECTION OF MATERIALS 2005). FEDERAL DATA FOR THE ACADEMIC YEAR 2007-08; THIS NUMBER REINFORCES THE ARgUMENT ABOUT THE VIRTUAL ELIMINATION OF NATIVE LANgUAgE INSTRUCTION IN PREVIOUS YEARS.

Table 4. Teaching of Finno-Ugric languages in the Republic of Bashkortostan

\begin{tabular}{|c|c|c|c|c|c|}
\hline Language & Bashkir & Tatar & Mari & Udmurt & Mordvin \\
\hline Year & $1988 / 1989$ & $1988 / 1989$ & $1990 / 1991$ & $1990 / 1991$ & $1990 / 1991$ \\
\hline Instruction & 43,933 & 19,496 & 4,305 & 699 & 0 \\
\hline Instruction $\%^{\mathrm{a}}$ & $\sim 31 \%$ & $\sim 10 \%$ & $26.5 \%$ & $\sim 15 \%$ & 0 \\
\hline Native $^{\mathrm{a}}$ & 93,950 & $\sim 77,000$ & $\mathrm{n} / \mathrm{a}$ & $\mathrm{n} / \mathrm{a}$ & 0 \\
\hline Ethnic share ${ }^{a}$ & $66.1 \%$ & $39.5 \%$ & $\mathrm{n} / \mathrm{a}$ & $50.5 \%$ & 0 \\
\hline Year & $1995 / 1996$ & $1995 / 1996$ & $1995 / 1996$ & $1995 / 1996$ & 1995/1996 \\
\hline Instruction & 63,594 & 22,936 & 5,647 & 877 & 0 \\
\hline Instruction \% & $39.1 \%$ & $11.1 \%$ & $28.2 \%$ & $20.7 \%$ & 0 \\
\hline Native & 114,877 & 97,747 & 11,280 & 2,177 & 112 \\
\hline Ethnic share & $70.6 \%$ & $47.2 \%$ & $56.3 \%$ & $51.4 \%$ & $5 \%$ \\
\hline Year & $1999 / 2000$ & $1999 / 2000$ & $1999 / 2000$ & $1999 / 2000$ & $1999 / 2000$ \\
\hline Instruction & 69,975 & 23,264 & 5,337 & 512 & 0 \\
\hline Instruction \% & $39.7 \%$ & $10.6 \%$ & $25.2 \%$ & $11.2 \%$ & 0 \\
\hline Native & 138,000 & 123,114 & 17,672 & 3,291 & 284 \\
\hline
\end{tabular}




\begin{tabular}{|l|l|l|l|l|l|}
\hline Ethnic share & $78.3 \%$ & $56.5 \%$ & $58.3 \%$ & $60.8 \%$ & $8.6 \%$ \\
\hline Year ${ }^{\text {b }}$ & $\mathbf{2 0 0 3 / 2 0 0 4}$ & $\mathbf{2 0 0 3 / 2 0 0 4}$ & $\mathbf{2 0 0 3 / 2 0 0 4}$ & $\mathbf{2 0 0 3 / 2 0 0 4}$ & $\mathbf{2 0 0 3 / 2 0 0 4}$ \\
\hline Instruction & 63,813 & 14,752 & 4,233 & 344 & 0 \\
\hline Instruction \% & $41.2 \%$ & $8.3 \%$ & $23.5 \%$ & $9 \%$ & 0 \\
\hline Native & 135,965 & 107,824 & 15,385 & 2,829 & 391 \\
\hline Ethnic share & $87.8 \%$ & $58 \%$ & $61.8 \%$ & $64.7 \%$ & $16.4 \%$ \\
\hline Year & $2009 / 2010$ & $2009 / 2010$ & $2009 / 2010$ & $2009 / 2010$ & $2009 / 2010$ \\
\hline Instruction & 47,908 & 10,042 & 2,809 & 248 & 0 \\
\hline Instruction \% & $37.8 \%$ & $8.4 \%$ & $20.8 \%$ & $8.6 \%$ & 0 \\
\hline Native & 126,747 & 64,801 & 9,130 & 1,824 & 410 \\
\hline Ethnic share & $99.9 \%$ & $54.1 \%$ & $67.34 \%$ & $63.3 \%$ & $26.9 \%$ \\
\hline
\end{tabular}

A THE Official dATA ARE AVAILABLE FOR THE YEAR 1992-93 ONLY. THE Official DATA ARE AVAILABLE ONLY ON THE SHARE OF THE STUDENTS HAVING THE BASHKIR AND TATAR LANGUAgE OF INSTRUCTION AMONg ALL STUDENTS IN THE REPUBLIC IN 1988-89 (RESPECTIVELY, 8.2\% AND 3.6\%); ACCORDINg TO THE 1989 POPULATION CENSUS THE SHARE OF BASHKIRS WAS 22\% AND TATARS $28 \%$ IN THE TOTAL POPULATION OF THE REPUBLIC.

B THE Official dATA ARE AVAILABLE FOR THE YeAR 2003-04 ONLY.

Table 5. Teaching of the Finno-Ugric languages in the Republic of Tatarstan

\begin{tabular}{|l|l|l|l|l|l|}
\hline Language & Tatar & Bashkir & Mari & Udmurt & Mordvin \\
\hline Year & $\mathbf{1 9 9 0 / 1 9 9 1}$ & $\mathbf{1 9 9 0 / 1 9 9 1}$ & $\mathbf{1 9 9 0 / 1 9 9 1}$ & $\mathbf{1 9 9 0 / 1 9 9 1}$ & $\mathbf{1 9 9 0 / 1 9 9 1}$ \\
\hline Instruction & 65,074 & 0 & 236 & 757 & 40 \\
\hline Instruction \% & $\sim 26.6 \%^{\mathrm{a}}$ & 0 & $\mathrm{n} / \mathrm{a}$ & $\mathrm{n} / \mathrm{a}$ & $\mathrm{n} / \mathrm{a}$ \\
\hline Native & $\sim 192,600$ & 0 & $\mathrm{n} / \mathrm{a}$ & $\mathrm{n} / \mathrm{a}$ & $\mathrm{n} / \mathrm{a}$ \\
\hline Ethnic share & $\sim 78.6 \%$ & 0 & $\mathrm{n} / \mathrm{a}$ & $\mathrm{n} / \mathrm{a}$ & $\mathrm{n} / \mathrm{a}$ \\
\hline Year & $\mathbf{1 9 9 5 / 1 9 9 6}$ & $\mathbf{1 9 9 5 / 1 9 9 6}$ & $\mathbf{1 9 9 5 / 1 9 9 6}$ & $\mathbf{1 9 9 5 / 1 9 9 6}$ & $\mathbf{1 9 9 5 / 1 9 9 6}$ \\
\hline Instruction & 116,500 & 0 & $\mathrm{n} / \mathrm{a}$ & $\mathrm{n} / \mathrm{a}$ & 0 \\
\hline Instruction \% & $43 \%$ & 0 & $\mathrm{n} / \mathrm{a}$ & $\mathrm{n} / \mathrm{a}$ & 0 \\
\hline Native & 248,700 & 0 & $\mathrm{n} / \mathrm{a}$ & $\mathrm{n} / \mathrm{a}$ & $\mathrm{n} / \mathrm{a}$ \\
\hline Ethnic share & $95.8 \%{ }^{\mathrm{a}}$ & 0 & $48 \%$ & $66.8 \%$ & $11 \%$ \\
\hline
\end{tabular}




\begin{tabular}{|l|l|l|l|l|l|}
\hline Year & $\mathbf{2 0 0 0 / 2 0 0 1}$ & $\mathbf{2 0 0 0 / 2 0 0 1}$ & $\mathbf{2 0 0 0 / 2 0 0 1}$ & $\mathbf{2 0 0 0 / 2 0 0 1}$ & $\mathbf{2 0 0 0 / 2 0 0 1}$ \\
\hline Instruction & 150,632 & 0 & $\mathrm{n} / \mathrm{a}$ & $\mathrm{n} / \mathrm{a}$ & 0 \\
\hline Instruction \% & $48 \%$ & 0 & $\mathrm{n} / \mathrm{a}$ & $\mathrm{n} / \mathrm{a}$ & 0 \\
\hline Native & 313,750 & 0 & 1,274 & 2,419 & 108 \\
\hline Ethnic share & $99.6 \% \mathrm{a}$ & 0 & $49 \%$ & $71 \%$ & $8 \%$ \\
\hline Year ${ }^{\mathrm{b}}$ & $\mathbf{2 0 0 3 / 2 0 0 4}$ & $\mathbf{2 0 0 3 / 2 0 0 4}$ & $\mathbf{2 0 0 3 / 2 0 0 4}$ & $\mathbf{2 0 0 3 / 2 0 0 4}$ & $\mathbf{2 0 0 3 / 2 0 0 4}$ \\
\hline Instruction & 129,653 & 0 & $\mathrm{n} / \mathrm{a}$ & $\mathrm{n} / \mathrm{a}$ & 0 \\
\hline Instruction $\%$ & $51.9 \%$ & 0 & $\mathrm{n} / \mathrm{a}$ & $\mathrm{n} / \mathrm{a}$ & 0 \\
\hline Native & 249,805 & 28 & 1,268 & 2,356 & 186 \\
\hline Ethnic share & $99.8 \%$ & $\mathrm{n} / \mathrm{a}$ & $49 \%$ & $70 \%$ & $8 \%$ \\
\hline Year ${ }^{\mathrm{b}}$ & $\mathbf{2 0 1 0 / 2 0 1 1}$ & $\mathbf{2 0 0 7 / 2 0 0 8}$ & $\mathbf{2 0 0 7 / 2 0 0 8}$ & $\mathbf{2 0 0 7 / 2 0 0 8}$ & $\mathbf{2 0 0 7 / 2 0 0 8}$ \\
\hline Instruction & 85,516 & 0 & 218 & 348 & 0 \\
\hline Instruction \% & $46.13 \%$ & 0 & $15.3 \%$ & $14.5 \%$ & 0 \\
\hline Native & 185,392 & 54 & 683 & 1,488 & 118 \\
\hline Ethnic share & $100 \%$ & $15 \%$ & $48 \%$ & $62.3 \%$ & $8.6 \%$ \\
\hline
\end{tabular}

A THE Official datA ARE AVAILABLE ONLY ON THE SHARE OF THE STUDENTS hAVINg THE TATAR LANGUAgE OF INSTRUCTION AMONg ALL STUDENTS IN THE REPUBLIC: IN 1990-91 IT WAS 12.9\%, IN 1995-96 ALREADY 91.8\%, AND 99.1\% IN 2000-01; THE SHARE OF TATARS ACCORDINg TO THE 1989 POPULATION CENSUS WAS 48.5\% IN THE TOTAL POPULATION OF THE REPUBLIC.

B THE OFfICIAL DATA ARE AVAILABLE FOR THE YEARS 2003-04 AND 2007-08 ONLY.

All three modes of language teaching were present throughout the considered period:

1. Formally, teaching of the titular state languages in Komi and Mari El has been mandatory to pupils of both titular and other nationalities since the early 1990s. Despite the specific provision demanding that state languages have to be taught at all schools, so far it is not even taught to all schoolchildren of titular nationalities. Nevertheless, a sign of efficient policy is the fact that in both republics language teaching is made available in urban schools. The policy of the Komi Republic is remarkable for its steadiness in extending state language teaching, slowed down, however, in the last years. In the Republic of Mari El the amount of state language teaching underwent a major fall after 2001 due to the mentioned political developments. In Mordovia, despite the late start of the extension of state language teaching to all students, the share of students covered is comparable to those of the other two republics. All this could have been evaluated as policy efficiency dynamics if it weren't for one trend: the data from all the three republics suggest that the state language teaching expanded at the expense of native language teaching. 
2. Teaching of native language is currently the mode that is the most sensitive to change. In line with political developments, the efforts of regional education authorities directed at language revival in the 1990s have led to a gradual increase in the amount of native language teaching. Before 1995, by applying affirmative action in language planning in most republics both absolute numbers and percentages among the pupils of titular nationality of those who studied their mother tongues as native language grew moderately. The exception was Mordovia where these numbers and percentages were decreasing slightly. After 1995, and particularly after 2000, both absolute numbers and relative shares of pupils studying native languages (and, in Mordovia and Mari El, also the numbers of pupils instructed in native languages) decreased due both to demographic recession and political factors, discussion of which is beyond the scope of this study. The total number of schoolchildren in Russia has been decreasing since the turn of the millennium due to a demographic recession. This explains the corresponding drop in absolute numbers of pupils studying state and native languages in republics after 2000.

The exception was Karelia where the absolute number of pupils studying their native languages has decreased since 2002 although their relative share continued to grow until 2005, inter alia, because of the 'low start'. However, the number of teaching hours for the Karelian language is small (one to three hours per week) and the continuity between education stages is weak. As regards Mordovia, it is difficult to evaluate developments due to insufficient data; it could be said at least that, with a delay typical of this republic both in the initiation of language revival policy and in its decay, the absolute number of pupils studying native languages remained stable until 2005.

The results of this study show that mother tongues are currently taught as native or state language to over half of schoolchildren of titular origin in Komi and far more than half in Mari El, and to about half the schoolchildren in Mordovia (see Table 3). Less than half the schoolchildren of titular origin are taught their language as native in Mari El and Udmurtia, and only about a quarter in Komi, Mordovia and Karelia. Almost every sixth pupil in Mari El, almost half schoolchildren in Mordovia and Komi, more than a half in Udmurtia, and three out of four schoolchildren in Karelia do not have access to learning their language in any mode. In the Turkic Republics, native language teaching for Finno-Ugric minorities was provided to two out of three Udmurt and Mari students in Bashkortostan as well as two out of three Udmurt students and almost a half of Mari students in Tatarstan; that is, on a wider scale than in the titular Mari El Republic and Udmurtia. In Tatarstan and Bashkortostan the teaching of Finno-Ugric languages remained stable over time (see Tables 4 and5).

Apart from the republics, the policy of language revival was adopted in other regions as well, in particular titular languages in the autonomous districts. The institutional base was created there later than in many republics, that is, around the turn of millennium, which implies its weakness. Teaching native languages of indigenous small numbered peoples is somewhat better organised in relation to those languages that are supported by assigning them some functions of official languages in autonomous districts. However, the mere act of designating official status to a language has not automatically improved its position within the education system. In the area of education those languages remained taught as native languages only. The study demonstrated that the prevalence of teaching titular languages of indigenous small numbered peoples in autonomous districts is often comparable to those in the republics. In addition to their 
official status a relatively small number of students and, thus, available funding in reach regions might be among the reasons for such a good situation: in the Nenets $A D$, native languages are taught to nearly one quarter of pupils of titular origin, in the Khanty-Mansi AD to about one third, and in the Yamal-Nenets AD to close to half. In the diaspora, on the contrary, coverage of pupils with language teaching is meagre. In the most unprivileged situation are the languages of peoples, including the indigenous ones, who have no titular administrative units of their own in Russia.

102 3. Extension of native language of instruction to all students is a goal of the language policy only in the Turkic Republics of Bashkortostan and Tatarstan, but not in the Finno-Ugric republics and regions. Both in Bashkortostan and Tatarstan systemic measures were undertaken to achieve this goal and currently about $59 \%$ of Tatars and $45 \%$ of Bashkirs in the titular republics have the native language of instruction (Artemenko 2010, pp. 47-48). This goal was not achieved for Finno-Ugric minorities although the share of students having native language of instruction remains quite stable, though slowly declining after the turn of the millennium. On the contrary, in Mari El and Mordovia, where since the Soviet period the native language of instruction remained in rural schools, the number of pupils instructed in their native language at elementary school started declining as far back as the late 1990s, and has declined particularly sharply since the early 2000s. The mass transition of schools from native to Russian as the language of instruction in both Mari El and Mordovia began mostly in 2001-02, that is, prior even to the 2007 education reform. This decline was somewhat masked by the general fall in numbers caused by the demographic recession, particularly in rural areas. Schooling in the native language has now practically disappeared in Mari El and functions in a significantly reduced state in Mordovia.

The quantitative results elucidate some qualitative parameters. As a result of the unification of state education standards after the 2007 reform, the number of hours assigned for language teaching has decreased, which directly affected its quality. As the data show, native language teaching is organised mostly in rural schools, usually small rural schools, which often provide only primary or basic secondary education in Udmurtia and Mordovia as well as in Komi and Mari El (even if in the latter two in urban schools the titular state language is taught). That is why even if formally the model of school with the Russian language of instruction and teaching of native language as a subject up to 11th grade is in use in all regions, in reality many children learn the latter only for several years. In addition, it is commonly recognised that rural schools typically provide a lower quality of overall education than urban schools.

Urban schools are ineffective for another reason. Often the native language is taught in classes at urban schools extracurricularly as an optional subject in a lesser amount of two or three hours. As in the case with foreign languages, this number of teaching hours in combination with the lack of a linguistic environment means that schoolchildren miss communicative skills after completion of school. This raises the problem of ineffective methodology. A low social status of minority languages in urban areas hardly provides any incentives for language learning. Since 2011 it has been possible in some republics for schoolchildren to pass optional final examinations, but only Russian is used in the later stages of education. Very few schools provide high quality education: in every republic there would be one school, such as Syktyvkar Komi National Gymnasium, Izhevsk Kuzebay Gerd Udmurt National Gymnasium, 
Petrozavodsk Finno-Ugric School. In sum, among those with access to language learning only a few gain good language competence.

\section{Conclusion}

Writing about nationalist mobilisation and its influence on regional policies, Dmitry Gorenburg (2003, p. 200) separates the phase of creation of an institutional and symbolic framework for nationalist policy legitimisation in the republics from the phase of the policy implementation and gives the number of variables influencing the extent of accomplishments taken at both phases. In line with his distinction, the current study demonstrated that the legal-institutional framework was an indispensable prerequisite for language revival at its initial stage. The analysis of the policy-defining and legal documents demonstrates that the policy-makers considered the compulsory teaching of languages to be the most important tool of language revival. The institutional framework for the extension of native language teaching was created in many republics by the adoption of language laws or at least education laws between 1990 and 1995. The republics that managed to adopt language laws in that period, including Komi and Mari El, achieved more in the expansion of language teaching, including compulsory teaching of the state languages and greater access to native language learning. However, as a result of a mixture of some objective and subjective obstacles, the goal of the expansion of native and state language teaching was never fully achieved, even in those Finno-Ugric republics with an early start to language revival projects. Thus, the analysis demonstrated that compulsory language teaching turned to be only a very limited tool.

106 One of the reasons for this situation is the policy-making rather than rights-based approach chosen for regulation of language issues. Despite their formal recognition, the rights are not self-executive and substituted by administrative decision. That is why the right to receive education in the native language for the Finno-Ugric languages is not fulfilled and remains only on paper. The right to learn one's own language is exercised as an individual right based on free choice but mostly in republics and autonomous regions. Theoretically it should be possible to exercise this right in any region to any language of a people of Russia, which in practice is usually restricted to titular languages because only in republics and autonomous districts are the institutional conditions for language education created: teachers are trained, textbooks prepared and auxiliary measures taken. During the first years of language revival there were objective obstacles for achieving the goal, such as a lack of financial resources as well as qualified teachers and teaching materials. In these conditions much depended on the position of implementers, in particular, the regional education agencies, on their ability to push through the systemic measures.

Unlike in many former Union republics, in former autonomous republics predominantly Russian-speaking old Soviet nomenklatura largely retained its leading position. In the mid 1990s proponents of language revival started to lose their positions first in regional parliaments and later in governments, including the loss of a key figure of the minister of education. Around the turn of the millennium with the election of a new President, as a part of the overall federal policy shift towards recentralisation and strengthening of the 'power vertical', the federal authorities imposed the first wave of amendments to regional legislations in order to bring them 'into compliance with 
federal legislation' according to the principle of supremacy of the latter. Regional Russian elites perceived this shift as a move towards the desovereignisation of the republics and hindrance of the nationalist agenda implementation, including discouraging the extension of language teaching in the regions (see Zamyatin 2013). As was demonstrated in the analysis, around that time the structures responsible for developing national education were lowered in the governmental hierarchy. Nevertheless, the ability of regional education agencies to maintain consistency and continuity in policy implementation through administrative measures, as in the Komi Republic, despite the tightening of the federal grasp and challenges of the Russianspeaking elites, proved to be more important than mere legal regulation and institutional support.

108 The 2007 reform of the education system affected both the quantity and quality of native language teaching. So far, the changes have not largely altered the institutional settings of language education at the federal level. Yet, even though the three modes of language teaching have remained in place, language education policy in post-Soviet Russia changed dramatically. The implementation of language revival policies in many regions was practically stopped. Once more the regional language laws and education laws had to be amended in the division of competences. As a result of the amendments, the institutional differences between the republics were largely extinguished. Furthermore, as a consequence of the education reform 2007, the institutional base of language revival in the republics was narrowed. Since 2007, education authorities of constituent entities of the Russian Federation have been restricted in their ability to pursue language education policies. They can no longer impose on schools the selection of the language of instruction and interfere with the choice of teaching the native language as a subject. In other words, owing to the education reform, the regional education agencies have been stripped of the means to directly influence both the choice of the native language as a school subject by parents and the selection of the native language of instruction by an education institution. During the twenty-year effort of language revival, the republics had been seeking to increase demand to the level of supply; now the reform of 2007 heralded a drop in supply to the level of demand. It can be readily predicted that the number of native language learners among children will further decrease because parents will refuse to include the language into the school curriculum, or simply not express interest in it. Therefore, the reform has aggravated the already adverse situation of Finno-Ugric languages in the education system.

The school now has exclusive authority to decide over the very introduction, and volume, of language teaching. Thus, it becomes the central agent of language education policy. The education reform could reassess this new situation by providing a proper scientific back up. However, on the contrary, the reform resulted in narrowing of scientific support: in the last years scientific national education institutes were dissolved and merged to republican institutes of the development of education. Language policy in school and the issues such as the motivation and demands of schoolchildren and their parents become central in the discourse (see Sagitova 2011; Klementiev 2010a, b, 2011a, b; Martynenko 2011a, b and others). There is a strong likelihood that the effect of free choice of language learning introduced by the reform will further negatively affect the teaching of native Finno-Ugric languages (see Zamyatin 2012b, pp 96-97). One of side effects of language revival is that parents are used to reassign the responsibility for language transmission to the school. The return 
of responsibility to the parent in the conditions of discouragement of language teaching will predictably lead to a refusal to take responsibility, and a lack of linguistic demand expressed by parents and will further result in a lack of access to native language learning for a significant number of children.

What does only some children having access to native language learning mean? In the conditions where, in many families, intergenerational language transmission practically stopped, school remained an important mechanism in language transmission to new generations for a significant portion of students. Even for those students who still grow up with their native language in their family, the absence of native language teaching in school will result in their secondary socialisation in the majority language, whereas the native language will be restricted to the 'kitchen'. Instead of potentially benefiting from bilingualism, they will find themselves in a disadvantageous situation, often ending knowing neither native nor majority language properly. Thus, the absence of native language teaching will result in the acceleration of language shift and further ethnic assimilation. The overall number of students in Russia has almost halved during the last decade. It will be safe to guess that because of the failure of the language revival the absolute number of individuals reporting themselves as belonging to the Finno-Ugric peoples in Russia will decrease within the next generation by far more than a half.

\section{BIBLIOGRAPHY}

\section{Policy documents and legal acts cited in the article}

Second Report of the Russian Federation on the Implementation of Provisions of the Framework Convention for the Protection of National Minorities. 26 April 2005.

Third Report of the Russian Federation on the Implementation of Provisions of the Framework Convention for the Protection of National Minorities. 9 April 2010.

Constitution of the Russian Federation of 12 December 1993;

Law of the Russian Soviet Federative Socialist Republic On the Languages of the Peoples of the Russian Soviet Federative Socialist Republic of 25 October 1991 №1807-I (as amended by the Federal Law of 24 July 1998 №126 and the Federal Law of 11 December 2002 №165);

Law of the Russian Federation On Education of 10 July 1992 №3266-I (as amended by the Federal Law of 13 January 1996 №12 and the Federal Law of 3 June 2011 №121);

Federal Law On Amendments to Selected Legislative Acts of the Russian Federation Concerning Changing the Notion and Structure of the State Educational Standard of 1 December 2007 №309;

Federal Law On Education in the Russian Federation of 29 December 2012 №273;

Typical Provisions Concerning General Educational Institutions, approved by the Decree of the Government of the Russian Federation of 19 March 2001 №196; 
Decree of the Government of the Russian Federation On Restructuring of the Network of Educational Institutions Situated in the Rural Areas of 17 December 2001 №871;

Concept of Restructuring of the Network of Educational Institutions Situated in the Rural Areas, approved by the Order of the Ministry of Education of the Russian Federation of 16 January 2002 №103;

Federal Core Curriculum of the Russian Federation, including Sample Syllabi for Education Institutions of the Russian Federation Implementing General Education Programmes, approved by the Order of the Ministry of Education of the Russian Federation of 9 March 2004 №1312 (as amended by the Order of the Ministry of Education and Science of the Russian Federation of 30 August 2010 №889);

Decree of the Constitutional Court of the Russian Federation On the Case of the Examination of the Constitutionality of the Provisions in Section 2, Article 10 of the Law of the Republic of Tatarstan On the Languages of the Peoples of the Republic of Tatarstan, Part 2, Article 9 of the Law of the Republic of Tatarstan On the State Languages And the Other Languages of the Peoples of the Republic of Tatarstan, Section 2, Article 6 of the Law of the Republic of Tatarstan On Education, and Section 6, Article 3 of the Law of the Russian Federation On the Languages of the Peoples of the Russian Federation in relation to the Complaint of the Citizen S. Khapugin and the Request of the State Council of the Republic of Tatarstan and the Supreme Court of the Republic of Tatarstan of 16 November 2004 №16-P;

Priority Directions for the Development of the Education System of the Russian Federation and Complex of Actions for the Implementation of the Priority Directions for the Development of the Education System of the Russian Federation for the Period Until 2010, approved by the Decree of the Government of the Russian Federation of 9 December 2004, record №47;

Concept of the National Education Policy of the Russian Federation, approved by the Order of the Ministry of Education of the Russian Federation of 3 August 2006 №201;

Federal Law On Personal Data of 27 July 2006 №152;

Order of the Ministry of Education of the Russian Federation On Progress in Optimisation of the Network of Subordinate Education Institutions of 25 May 2007 №921;

Federal Law On Amendments to Selected Legislative Acts of the Russian Federation Concerning Changing the Notion and Structure of the State Education Standard of 1 December 2007 №309;

Decree of the Government of the Russian Federation On Measures for Implementation of the Decree of the President of the Russian Federation 'On Evaluation of Effectiveness of Activities of the State Executive Authorities of the Subjects of the Russian Federation of 28 June 2007 №825’ of 15 April 2009 №322;

Federal Target Programme of the Development of Education for 2011-15, approved by the Decree of the Government of the Russian Federation of 7 February 2011 №61;

Law of the Komi Republic On the State Languages of the Komi Republic of 28 May 1992;

Law of the Komi Republic On Education of 28 December 1993;

Law of the Komi Republic On the Amendment to the Law of the Komi Republic On Education of 27 February 1998;

Sample syllabus for education institutions with Russian (not native) language of instruction approved by the decree of the Minister of Education and Higher School of 12 April 1999; 
Decree of the Constitutional Court of the Komi Republic On the Case of the Examination of the Constitutionality of Section 4, Article 6 of the Law of the Komi Republic On Education (revised 27 February 1998) in relation to the Complaint of the Citizen L. Koltyrina of 22 May 2002;

Law of the Komi Republic On Education of 6 October 2006;

Decree of the Constitutional Court of the Komi Republic On the Case of the Examination of the Constitutionality of Section 4, Article 1-1 of the Law of the Komi Republic On Education (6 October 2006, Article included by the Law of the Komi Republic 15 November 2006) in relation to the Complaint of the Citizen O. Luniova of 1 September 2011;

Law of the Republic of Mari El On Education of 4 November 1992;

Decree of the Supreme Council of the Republic of Mari El On the Procedure of Enactment of some provisions of the Law of the Republic of Mari El On Education of 4 November 1992;

Law of the Republic of Mari El On the Languages of the Republic of Mari El of 26 October 1995;

State Programme of the Development of Education of the Republic of Mari El approved by the Decree of the State Assembly of the Republic of Mari El of 25 July 1995;

Decree of the Government of the Republic of Mari El On the Issues of the Ministry of Education of the Republic of Mari El of 29 March 2001;

Decree of the Government of the Republic of Mari El On Measures for the Optimization of the Network of the Education Institutions of the Republic of Mari El in 2004-08 of 24 May 2004;

Law of the Republic of Mari El On Regulation of Relations in the Sphere of Education on the Territory of the Republic of Mari El of 29 March 2001 (as amended by the Laws of the Republic of Mari El of 3 May 2006 and 7 May 2008);

Republican Target Programme of the Development of Education of the Republic of Mari El for 2008-10 approved by the Law of the Republic of Mari El of 18 October 2007;

Republican Target Programme of the Development of Education of the Republic of Mari El 201115 approved by the Decree of the Government of the Republic of Mari El of 7 December 2010;

Law of the Republic of Mordovia On the State Languages in the Republic of Mordovia of 24 April 1998 (as amended by the Law of the Republic of Mordovia of 12 March 2010);

Law of the Republic of Mordovia On Education in the Republic of Mordovia of 17 November 1998 (as amended by the Law of the Republic of Mordovia of 12 March 2010);

Order of Ministry of Education the Republic of Mordovia On Enforcement of Legislation of the Russian Federation and the Republic of Mordovia in the field of language policy in the education institutions of the Atiashevskii district of 20 May 2004;

Order of Ministry of Education the Republic of Mordovia On Approbation of the New Content of Education in Subjects 'Moksha Language' and 'Erzya Language' in Primary School with Russianspeaking and Nationally Mixed Contingents of Pupils of 8 October 2004;

'Methodic Recommendations of Republic of Mordovia Ministry of Education On Teaching the Mordvin (Moksha, Erzya) Languages and Literature in the General Education Institutions in the 2009-10 Academic Year'. Approved by Order of RM Ministry of Education of 28 August 2009;

Law of the Udmurt Republic On Public Education of 31 January 1996 (as amended by the Law of the Udmurt Republic of 24 April 2001);

Law of the Udmurt Republic On the State Languages of the Udmurt Republic and Other Languages of the Peoples of the Udmurt Republic of 27 November 2001; 
Law of the Udmurt Republic On Education of 16 April 2004;

Law of the Udmurt Republic On Exercising Powers of the Udmurt Republic in the Sphere of Education of 15 December 2009;

Concept of the Development of National Education in the Udmurt Republic, approved by the UR Ministry of Public Education Board Decision of 24 January 1991;

Concept of the Development of National Education in the Udmurt Republic, approved by the UR Ministry of Public Education Board Decision of 27 January 2000;

'Methodic Recommendations on Arranging the Teaching of Native (Non-Russian) Languages in the General Educational Institutions of the Udmurt Republic'. UR Ministry of Education and Science Communications of 25 March 2011 and 29 April 2011;

Regulation on the Methods and Procedure for Conducting State (Final) Certification in Native Language and Native Literature for Those Students of the Udmurt Republic Who Have Completed the Main General Educational Programmes of Basic Secondary and Secondary Complete Education, approved by the Order of the Ministry of Education and Science of the Udmurt Republic of 7 February 2012;

Law of the Republic of Karelia On the State Support of the Karelian, Veps and Finnish Languages in the Republic of Karelia of 19 March 2004;

Law of the Republic of Karelia On Education of 29 April 2005 (as amended by the Law of the Republic of Karelia of 3 November 2011);

Decree of the Ministry of Education of the Republic of Karelia of 24 March 1998;

'On Teaching of the Karelian, Veps and Finnish Languages in the Conditions of the Enforcement of the Federal State Education Standards of Primary General Education'. RK Ministry of Education Communication of 8 June 2011;

Law of the Komi-Permyak Autonomous District On Education in the Komi-Permyak Autonomous District of 17 March 2005;

Complex Target Programme Development of the Education System of the Komi-Permyak Autonomous District for 2006-08 approved by the Law of the Komi-Permyak Autonomous District of 26 October 2005;

Law of the Perm Territory On Regulation of the Issues in the Sphere of Education of the Perm Territory of 12 March 2010;

Law of the Khanty-Mansi Autonomous District-Yugra On the Native Languages of the Indigenous Small Numbered Peoples of the North Residing on the Territory of the Khanty-Mansi Autonomous District-Yugra of 4 December 2001;

Law of the Khanty-Mansi Autonomous District-Yugra On Education in the Khanty-Mansi Autonomous District-Yugra of 11 November 2005 (as amended by the Law On Amendments of 19 September 2008);

The National Regional Component of the Khanty-Mansi Autonomous District-Yugra, approved by the Decree of the Government of the Khanty-Mansi Autonomous District-Yugra of 31 August 2005; Core Study Plan of the Khanty-Mansi Autonomous District-Yugra, approved by the Order of the Department of Education and Science of the Khanty-Mansi Autonomous DistrictYugra of 14 September 2005; 
District Target Programme of the Development of Education in the Khanty-Mansi Autonomous District-Yugra (for 2008-10) approved by the Law of the Khanty-Mansi Autonomous DistrictYugra of 31 October 2007;

Law of the Yamal-Nenets Autonomous District On Education in the Yamal-Nenets Autonomous District of 31 January 2000;

Law of the Yamal-Nenets Autonomous District On the Native Languages of the Indigenous Small Numbered Peoples of the North Residing on the Territory of the Yamal-Nenets Autonomous District of 5April 2010;

District target programme Culture, Language, Traditional Way of Life (for 2008-11) approved by the Law of the Yamal-Nenets Autonomous District of 27 June 2006;

Law of the Nenets Autonomous District On Education of 15 January 1998;

District Target Programme of the Development of Education in the Nenets Autonomous District (for 2006-10) approved by the Law of the Nenets Autonomous District of 21 April 2006;

Law of the Republic of Bashkortostan On the Languages of the Republic of Bashkortostan of 15 February 1999 (as amended by the Law of the Republic of Bashkortostan of 5 April 2004);

Law of the Republic of Bashkortostan On Education of 28 September 2005;

Decision of the Supreme Court of the Republic of Adygea of 19 December 2006 №3-32/2006.

'Report On Results and General Activities of Komi Republic Ministry of Education for 2010 and Further for 2011-13'. KR Ministry of Education, 2011.

'Information and Statistical Materials According to the Data of the State Statistics'. KR Information Centre of Assessing the Quality of Education, 2011.

Education in the Komi Republic: in Numbers and Facts. Syktyvkar: KR Information Centre of Assessing the Quality of Education, 2010, 2011.

'Data on Learning of the Native and State Mari Language, History and Culture of the Peoples in the Education Institutions of the Republic of Mari El'. Information of RME Ministry of Education, November 6, 2001.

'Collection of Materials On Ethnic Situation in the Republic of Mari El and Socio-Cultural Situation of the Mari People'. Ioshkar-Ola: Information-Political Department of RME Presidential Administration, 2005.

'Main Results of Republic of Mari El Ministry of Education and Science Activities in 2010'. Report at RME Ministry of Education Board of February 15, 2011.

'National Education in the Republic of Mordovia: State-of-Art, Problems and Perspectives'. Analytical Material. Bulletin of RM Scientific Centre for Social-Economic Monitoring 12, 2005.

'On Learning the Mordvin Languages in the Education Institutions of the Republic of Mordovia'. RM Ministry of Education Information. Bibliotechka zhurnala Vestnik obrazovaniia Rossii 8 (2008): 914.

'Network of Schools Providing Learning of the Mordvin (Moksha, Erzya) and Tatar Languages and Literature' (2009-10 Academic Year).

'Statistical Data and Indicators On the Situation and Dynamics of Development in the Economic, Social and Other Spheres Within the Competences of Ministry of Education'. Appendix A. Information of RM Ministry of Education, 2010. 
Press release of the Republic of Mordovia Public Prosecutor Office of 2 February 2010.

'Information On Activities of Department of National Education, Udmurt Republic Ministry of Education in 2007'.

'On Creation of Conditions for Satisfaction of Ethnocultural Educational Demands of Students of the General Educational Institutions'. UR Ministry of Education Board Decision of 30 June 2010.

'On Completing of Classes with Learning of Native Language and Literature in the General Educational Institutions for the 2012-13 Academic Year'. UR Ministry of Education Communication of 19 December 2011.

UR Ministry of Education Information. UR Deputy Minister of Education Presentation at the session of 'Pichi Kenesh' of 11 April 2012.

'Republic of Bashkortostan Ministry of Education Data for the 2008-09 Academic Year'. Ufa: RB President's Administration, 2009.

Concept of the Development of National Education in the Republic of Bashkortostan, approved by RB President's Decree of December 31, 2009.

'Data on Development of National Education in the Republic of Tatarstan 1991-2004' ' 2004-07'. RT Ministry of Education.

'Results of the Socio-Economic Development of the Komi-Permyak District After the Merger of the Komi-Permyak Autonomous District and the Perm Region and Perspectives of Further Development'. Report by the Head of the Komi-Permyak District - Minister of the Perm Territory, 2010.

Education of Indigenous Small Numbered Peoples in the Khanty-Mansi Autonomous District. Khanty-Mansiisk: KMAD Administration, 2005.

'Implementation of Ethnocultural Education of Indigenous Small Numbered Peoples of the North'. KMAD Education Department Information, 2008.

YNAD Education Department Information 2009.

YNAD Indigenous Peoples Department Report 2009.

'Learning of the Nenets language in the Nenets Autonomous District: the Data on the Distribution of the Educational Institutions and Students Depending on the Language of Instruction and Native (Non-Russian) Language Learning'. The Data of the Association of the Nenets People Iasavei, 2010.

'National Learning and Cultural Institutions of Saint-Petersburg'. Saint-Petersburg House of Nationalities, 2010.

Rossiiskii statisticheskii iezhegodnik. 2011. Moscow: Rosstat, 2011.

Finno-ugorskii mir. Statisticheskii sbornik. Syktyvkar: Komistat, 2008.

Natsionalnyi sostav naseleniia RSFSR. Po dannym Vsesoiuznoi perepisi naseleniia 1989 goda. Moscow: Goskomstat RSFSR, 1990.

'Natsionalnyi sostav naseleniia i vladenie iazykami, grazhdanstvo'. Itogi Vserossiiskoi perepisi naseleniia 2002 goda, Vol. 4 (1). Moscow: Statistika Rossii, 2004.

'Natsionalnyi sostav naseleniia po subiektam Rossiiskoi Federatsii. Prilozhenie 7'. Informatsionnye materialy ob okonchatelnykh itogakh Vserossiiskoi perepisi naseleniia 2010 goda. 
AREFIEV 2010 = А. АРЕФЬЕВ, «ДЕТИ ИЗ СЕМЕЙ ИНОСТРАННЫХ МИГРАНТОВ КАК НОВОЕ ЯВЛЕНИЕ В РОССИЙСКИХ ШКОЛАХ: СОЦИО-ЛИНГВИСТИЧЕСКИЕ И ЭКОНОМИЧЕСКИЕ АСПЕКТЫ», Demoscope Weekly, № 441 - 442 .

ARTEMENКO 2009 = О. АРТЕМЕНКО, «ВЫСТУПЛЕНИЕ. СТЕНОГРАММА ПАРЛАМЕНТСКИХ СЛУШАНИЙ», О МЕРАХ ПО РЕАЛИЗАЦИИ ЦЕЛЕЙ ВТОРОГО МЕЖДУНАРОДНОГО ДЕСЯТИЛЕТИЯ КОРЕННЫХ НАРОДОВ МИРА В СФЕРАХ НАРОДНОГО ОБРАЗОВАНИЯ И СОХРАНЕНИЯ РОДНЫХ ЯЗЫКОВ В РАЙОНАХ ПРОЖИВАНИЯ КОРЕННЫХ МАЛОЧИСЛЕННЫХ НАРОДОВ СЕВЕРА, СИБИРИ И ДАЛЬНЕГО ВОСТОКА РОССИЙСКОЙ ФЕДЕРАЦИИ: ПАРЛАМЕНТСКИЕ СЛУШАНИЯ, 02 ОКТЯБРЯ 2008 Г., МОСКВА: ИЗД. СОВЕТА ФЕДЕРАЦИИ, С. 8-18.

ARTЕMЕNКО 2010 = О. АРТЕМЕНКО, «ОБРАЗОВАНИЕ И ЯЗЫК: СОВРЕМЕННЫЙ РОССИЙСКИЙ ОПЫТ», ЭТНОПОЛИТИЧЕСКАЯ СИТУАЦИЯ В РОССИИ И СОПРЕДЕЛЬНЫХ ГОСУДАРСТВАХ В 2009 ГОДУ. ЕЖЕГОДНЫЙ ДОКЛАД СЕТИ ЭТНОЛОГИЧЕСКОГО МОНИТОРИНГА И РАННЕГО ПРЕДУПРЕЖДЕНИЯ КОНФЛИКТОВ, ПОД РЕД. В. ТИШКОВА И В. СТЕПАНОВА, МОСКВА: ИЭА РАН, С. 47-51.

CHERNYКH 2010 = А. ЧЕРНЫХ, «СИСТЕМА ЭТНОКУЛЬТУРНОГО ОБРАЗОВАНИЯ И ПРЕПОДАВАНИЯ РОДНОГО ЯЗЫКА В ПЕРМСКОМ КРАЕ», ЭТНОПОЛИТИЧЕСКАЯ СИТУАЦИЯ В РОССИИ И СОПРЕДЕЛЬНЫХ ГОСУДАРСТВАХ В 2009 ГОДУ. ЕЖЕГОДНЫЙ ДОКЛАД СЕТИ ЭТНОЛОГИЧЕСКОГО МОНИТОРИНГА И РАННЕГО ПРЕДУПРЕЖДЕНИЯ КОНФЛИКТОВ, ПОД РЕД. В. ТИШКОВА И В. СТЕПАНОВА, МОСКВА: ИЭА РАН, С. 67-72.

DYAСНКОV 1993 = М. ДЬЯЧКОВ, «МИНОРИТАРНЫЕ ЯЗЫКИ В РОССИИ», СОЦИОЛОГИЧЕСКИЕ ИССЛЕДОВАНИЯ, № 1, С. 113-115.

DYAСНКОV 2004 = М. ДЬЯЧКОВ, «СОХРАНЕНИЕ ЯЗЫКОВОГО МНОГООБРАЗИЯ - НЕОБХОДИМОЕ УСЛОВИЕ ПОЗНАНИЯ МИРА И СОХРАНЕНИЯ ОБЩЕМИРОВОЙ КУЛЬТУРЫ», МЕЖДУНАРОДНЫЙ НАУЧНО-ПРАКТИЧЕСКИЙ ЖУРНАЛ INTER-CULTUR@L-NET, № 3, 2004 ГОД.

Etnokulturnoe obrazovanie 2010 = ЭТНОКУЛЬТУРНОЕ ОБРАЗОВАНИЕ. МЕТОДЫ СОЦИАЛЬНОЙ ОРИЕНТАЦИИ РОССИЙСКОЙ ШКОЛЫ, РЕД. В. СТЕПАНОВ. ВЫП. 1, МОСКВА: ИЭА РАН, 2010 ГОД.

Entsiklopediia 2003 = ЭНЦИКЛОПЕДИЯ ОБРАЗОВАНИЯ В ЗАПАДНОЙ СИБИРИ, ТОМ 1, БАРНАУЛ: АЛТАЙСКИЙ ПОЛИГРАФИЧЕСКИЙ КОМБИНАТ.

GABOV 2006 = П. ГАБОВ, «РАЗВИТИЕ НАЦИОНАЛЬНОЙ ШКОЛЫ В КОНЦЕ ХХ ВЕКА: ИСТОРИЧЕСКИЕ АСПЕКТЫ И СОВРЕМЕННОЕ СОСТОЯНИЕ ИЗУЧЕНИЯ В НЕЙ РОДНОГО ЯЗЫКА (НА ПРИМЕРЕ РЕСПУБЛИКИ КОМИ)», ФИННОУГРОВЕДЕНИЕ, № 1, С. 100-107.

GABOV 2009 = П. ГАБОВ, ГОСУДАРСТВЕННАЯ ПОЛИТИКА И РЕАЛИИ РАЗВИТИЯ КОМИ НАЦИОНАЛЬНОЙ ШКОЛЫ ВО ВТОРОЙ ПОЛОВИНЕ ХХ ВЕКА, ДИССЕРТАЦИЯ НА СОИСКАНИЕ УЧЕНОЙ СТЕПЕНИ КАНДИДАТА ИСТОРИЧЕСКИХ НАУК, СЫКТЫВКАР: КОМИ НЦ УРО РАН.

GABOV \& PoPOV $2010=$ П. ГАБОВ, А. ПОПОВ, «ГОСУДАРСТВЕННАЯ ПОЛИТИКА И ФУНКЦИОНИРОВАНИЕ ФИННО-УГОРСКИХ ЯЗЫКОВ В СФЕРЕ ОБРАЗОВАНИЯ НА МАТЕРИАЛАХ РЕСПУБЛИКИ КОМИ (ВТОРАЯ ПОЛОВИНА ХХ - НАЧАЛО ХХІ ВЕКА)», НАУКА УДМУРТИИ, № 5 (43), С. $31-36$.

GABDRAFIKOV 2006а = И. ГАБДРАФИКОВ, «ЯЗЫК В БАШКОРТОСТАНСКОЙ ШКОЛЕ: ПОЛИТИКА И ПРАКТИКА ПОСЛЕДНИХ ЛЕТ», БЮЛЛЕТЕНЬ СЕТИ ЭТНОЛОГИЧЕСКОГО МОНИТОРИНГА И РАННЕГО ПРЕДУПРЕЖДЕНИЯ КОНФЛИКТОВ, № 68. 
GABDRAFIKOV 2006b = И. ГАБДРАФИКОВ, «ИЗУЧЕНИЕ БАШКИРСКОГО ЯЗЫКА СТАНЕТ ОБЯЗАТЕЛЬНЫМ», ЭТНОКОНФЕССИОНАЛЬНАЯ СИТУАЦИЯ В ПРИВОЛЖСКОМ ФЕДЕРАЛЬНОМ ОКРУГЕ. БЮЛЛЕТЕНЬ СЕТИ ЭТНОЛОГИЧЕСКОГО МОНИТОРИНГА И РАННЕГО ПРЕДУПРЕЖДЕНИЯ конФликтов, № 116.

GABDRAKHMANOVA 2006 = Г. ГАБДРАХМАНОВА, «ЭТНИЧНОСТЬ, ЯЗЫК, ОБРАЗОВАНИЕ. ПОЛИТИЧЕСКИЙ И ПРАКТИЧЕСКИЙ ОПЫТ ПОСТСОВЕТСКОГО ТАТАРСТАНА», КАЗАНСКИЙ ФЕДЕРАЛИСТ, № 4 (20), С. 45-59.

GABDULGAFAROVA 2006 = И. ГАБДУЛГАФАРОВА, «ЭТНОКУЛЬТУРНОЕ ОБРАЗОВАНИЕ ЭТНИЧЕСКИХ МЕНЬШИНСТВ КАК СОСТАВЛЯЮЩАЯ ЧАСТЬ РЕГИОНАЛЬНОЙ ЭТНОПОЛИТИКИ», КАЗАНСКИЙ ФЕДЕРАЛИСТ, № 4 (20), С. 17-22.

GALDIA Marcus, 2009, Russia's Linguistic Legislation in the Light of the European Charter for Regional or Minority Languages, Report for the Joint Programme of the Council of Europe, European Union and Russian Ministry of Regional Development 'National minorities in Russia: Development of Languages, Culture, Mass Media and Civil Society'.

GARIPOv et al. 2006 = М. ГАРИПОВ, А. ГАПИРОВА, Г. МУХАМЕДЬЯНОВА, « НАЦИОНАЛЬНАЯ ШКОЛА В ИННОВАЦИОННОМ РАЗВИТИИ РЕГИОНАЛЬНОЙ СИСТЕМЫ ОБРАЗОВАНИЯ », ВЕСТНИК ВОСТОЧНОЙ ЭКОНОМИКО-ЮРИДИЧЕСКОЙ ГУМАНИТАРНОЙ АКАДЕМИИ, № 1 (33), С. 7-24.

GATAULLINA 2001 = М. ГАТАУЛЛИНА, ВЕДУЩИЕ ТЕНДЕНЦИИ РАЗВИТИЯ ТАТАРСКОЙ НАЦИОНАЛЬНОЙ ШКОЛЫ (1985-2000 ГГ.), КАЗАНЬ: ПЕЧАТНЫЙ ДВОР.

GORBACHOV 2011 = А. ГОРБАЧЕВ, «НАЦИОНАЛЬНОЕ ОБРАЗОВАНИЕ В БАШКОРТОСТАНЕ В 1990-1999 ГОДЫ», ЭТНОСЫ И КУЛЬТУРЫ УРАЛО-ПОВОЛЖЬЯ: ИСТОРИЯ И СОВРЕМЕННОСТЬ: МАТЕРИАЛЫ V ВСЕРОССИЙСКОЙ НАУЧНО-ПРАКТИЧЕСКОЙ КОНФЕРЕНЦИИ МОЛОДЫХ УЧЕНЫХ, УФА: ИЭИ УРО РАН, C. $112-115$.

GoRENBURG Dmitry P., 2003, Minority Ethnic Mobilization in the Russian Federation, New York: Cambridge University Press, 297 p.

GoRENBURG Dmitry P., 2005, “Tatar Language Policies in Comparative Perspective: Why Some Revivals Fail and Some Succeed", Ab Imperio, 1, pp. 257-284.

GRANEY Katherine E. 1999, "Education Reform in Tatarstan and Bashkortostan: Sovereignty Projects in Post-Soviet Russia”, Europe-Asia Studies, 4 (51), pp. 611-632.

Iazyki v sisteme obrazovaniia 2011 = ЯЗЫКИ В СИСТЕМЕ ОБРАЗОВАНИЯ РЕСПУБЛИКИ ТАТАРСТАН: ПО МАТЕРИАЛАМ ЭТНОСОЦИОЛОГИЧЕСКОГО ИССЛЕДОВАНИЯ, ПОД РЕД. Р. МУСИНОЙ И ДР., КАЗАНЬ: ТАТАРСКОЕ КНИЖНОЕ ИЗДАТЕЛЬСТВО.

KAZAKEVITCH Olga, 2002, "Education of Indigenous Minorities of Russia in the 1930s and in the 1990s: Mother Tongue at School", in Lectures on Language Situation: Russia, Estonia, Finland, Kazuto Matsumura (ed.), Tokyo: University of Tokyo, pp. 1-34.

KAZIMOv et al. 2008 = А. КАЗИМОВ, Т. НИКИТИНА, А. ПОПОВ, «К ОЦЕНКЕ ЭТНИЧЕСКИХ ПРОЦЕССОВ У ФИННО-УГРОВ ПРИВОЛЖСКОГО ФЕДЕРАЛЬНОГО ОКРУГА (МАРИЙЦЫ, МОРДВА, УДМУРТЫ, КОМИПЕРМЯКИ)», ИДЕНТИЧНОСТЬ И ИЗМЕНЯЮЩИЙСЯ МИР: МАТЕРИАЛЫ К ДИСКУССИИ НА V ВСЕМИРНОМ КОНГРЕССЕ ФИННО-УГОРСКИХ НАРОДОВ, СЫКТЫВКАР: КОМИ НЦ УРО РАН, С. 48-60.

KHRUSLOV Georgy, 1998, "Language policy in Russia”, in Modern Language Learning and Teaching in Central and Eastern Europe: which diversification and how can it be achieved? Proceedings of the Second Colloquy of the European Centre for Modern Languages, Graz, Austria, 13-15 February 1997, Fink, B. (ed.), Strasbourg: Council of Europe, pp. 121-130. 
KIRJANEN 2010 = А. КИРЬЯНЕН, «ИНГЕРМАНЛАНДСКИЕ ФИННЫ И ФИНСКИЙ ЯЗЫК В ПЕТЕРБУРГЕ И ЛЕНИНГРАДСКОЙ ОБЛАСТИ - СОВРЕМЕННОЕ ПОЛОЖЕНИЕ», РОССИЙСКИЕ ФИННЫ: ВЧЕРА, СЕГОДНЯ, ЗАВТРА, ПОД РЕД. Е. КЛЕМЕНТЬЕВА, ПЕТРОЗАВОДСК: КАРЕЛЬСКИЙ НЦ РАН, С. 14-23.

KLEMENTIEV 2006а = Е. КЛЕМЕНТЬЕВ, «ЯЗЫКОВОЕ ПРАВО И ОБРАЗОВАТЕЛЬНАЯ ПОЛИТИКА (НА ПРИМЕРЕ РЕСПУБЛИКИ КАРЕЛИЯ)», КАЗАНСКИЙ ФЕДЕРАЛИСТ, № 1-2 (17-18), С. 182-195.

KLEMENTIEV 2006b = Е. КЛЕМЕНТЬЕВ, «РОЛЬ ШКОЛЫ В СОХРАНЕНИИ ПРИБАЛТИЙСКО-ФИНСКИХ ЯЗЫКОВ», БЮЛЛЕТЕНЬ СЕТИ ЭТНОЛОГИЧЕСКОГО МОНИТОРИНГА И РАННЕГО ПРЕДУПРЕЖДЕНИЯ конФликтов, № 65.

KLEMENTIEV 2006C = Е. КЛЕМЕНТЬЕВ, «РЕАЛИЗАЦИЯ ПРАВА НА СОХРАНЕНИЕ РОДНОГО ЯЗЫКА В РЕСПУБЛИКЕ КАРЕЛИЯ: СОСТОЯНИЕ, ПРОБЛЕМЫ, ПЕРСПЕКТИВЫ», КАЗАНСКИЙ ФЕДЕРАЛИСТ, № 4 (20), с. 9-16.

KLEMENTIEV 2006d = Е. КЛЕМЕНТЬЕВ, «ЯЗЫКОВОЕ ПРАВО И ПРАКТИКА», ФИННО-УГОРСКИЙ ВЕСТНИК, № 1 (40).

KLEMENTIEV 2007 = Е. КЛЕМЕНТЬЕВ, «РЕСПУБЛИКА КАРЕЛИЯ», ЭТНОПОЛИТИЧЕСКАЯ СИТУАЦИЯ И КОНФЛИКТЫ В ГОСУДАРСТВАХ СНГ И БАЛТИИ. ЕЖЕГОДНЫЙ ДОКЛАД ЗА 2006 ГОД, ПОД РЕД. В. ТИШКОВА И Е. ФИЛИППОВОЙ, МОСКВА: ИЭА РАН.

KLEMENTIEV 2008 = Е. КЛЕМЕНТЬЕВ, «О ПРАВЕ И ПРАКТИКЕ: ЯЗЫКОВОЙ АСПЕКТ В РЕСПУБЛИКЕ КАРЕЛИЯ», ИДЕНТИЧНОСТЬ И ИЗМЕНЯЮЩИЙСЯ МИР: МАТЕРИАЛЫ К ДИСКУССИИ НА V ВСЕМИРНОМ КОНГРЕССЕ ФИННО-УГОРСКИХ НАРОДОВ, СЫКТЫВКАР: КОМИ НЦ УРО РАН, С. 61-70.

KLEMENTIEV 2010a = Е. КЛЕМЕНТЬЕВ, «РЕСПУБЛИКА КАРЕЛИЯ: ШКОЛА КАК ЭТНОКУЛЬТУРНЫЙ ЦЕНТР», ЭТНОКУЛЬТУРНОЕ ОБРАЗОВАНИЕ. МЕТОДЫ СОЦИАЛЬНОЙ ОРИЕНТАЦИИ РОССИЙСКОЙ ШКОЛЫ, РЕД. В. СТЕПАНОВ, ВЫП. 1, МОСКВА: ИЭА РАН, С. 27-44.

KLEMENTIEV 2010b = Е. КЛЕМЕНТЬЕВ, «РЕСПУБЛИКА КАРЕЛИЯ», ЭТНОПОЛИТИЧЕСКАЯ СИТУАЦИЯ В РОССИИ И СОПРЕДЕЛЬНЫХ ГОСУДАРСТВАХ В 2009 ГОДУ. ЕЖЕГОДНЫЙ ДОКЛАД СЕТИ ЭТНОЛОГИЧЕСКОГО МОНИТОРИНГА И РАННЕГО ПРЕДУПРЕЖДЕНИЯ КОНФЛИКТОВ, ПОД РЕД. В. ТИШКОВА И В. СТЕПАНОВА, МОСКВА: ИЭА РАН, С. 298-304.

KLEMENTIEV 2011a = Е. КЛЕМЕНТЬЕВ, «РЕСПУБЛИКА КАРЕЛИЯ: ПРАВОВАЯ СИТУАЦИЯ В СФЕРЕ ЭТНОКУЛЬТУРНОГО И ЯЗЫКОВОГО ОБРАЗОВАНИЯ», ПРАВОВОЙ СТАТУС ФИННО-УГОРСКИХ ЯЗЫКОВ И ЭТНОКУЛЬТУРНЫЕ ПОТРЕБНОСТИ РОССИЙСКОЙ ШКОЛЫ, ПОД РЕД. В. А. ТИШКОВА, МОСКВА: ИП А. Г. ЯковлЕВ, С. 101-120.

KLEMENTIEV 2011b = Е. КЛЕМЕНТЬЕВ, «РЕСПУБЛИКА КАРЕЛИЯ: ЭТНОКУЛЬТУРНЫЕ И ЯЗЫКОВЫЕ ПОТРЕБНОСТИ ШКОЛЬНОГО ОБУЧЕНИЯ», ПРАВОВОЙ СТАТУС ФИННО-УГОРСКИХ ЯЗЫКОВ И ЭТНОКУЛЬТУРНЫЕ ПОТРЕБНОСТИ РОССИЙСКОЙ ШКОЛЫ, ПОД РЕД. В. А. ТИШКОВА, МОСКВА: ИП А. Г. ЯковлЕВ, С. 121-177.

KOVALYOVA 2012 = С. КОВАЛЕВА, «КАРЕЛЬСКИЙ ЯЗЫК В СИСТЕМЕ ОБРАЗОВАНИЯ РЕСПУБЛИКИ КАРЕЛИЯ», ЭТНОПОЛИТИЧЕСКАЯ СИТУАЦИЯ В РОССИИ И СОПРЕДЕЛЬНЫХ ГОСУДАРСТВАХ В 2011 ГОДУ. ЕЖЕГОДНЫЙ ДОКЛАД СЕТИ ЭТНОЛОГИЧЕСКОГО МОНИТОРИНГА И РАННЕГО ПРЕДУПРЕЖДЕНИЯ КОНФЛИКТОВ, ПОД РЕД. В. ТИШКОВА И В. СТЕПАНОВА, МОСКВА: ИЭА РАН, С. 309-320.

KOZULINA 2003 = С. КОЗУЛИНА, «ПРОБЛЕМЫ И ПЕРСПЕКТИВЫ РАЗВИТИЯ КОМИ ЯЗЫКА КАК ГОСУДАРСТВЕННОГО ЯЗЫКА РЕСПУБЛИКИ КОМИ», ПРОБЛЕМЫ И ПЕРСПЕКТИВЫ РАЗВИТИЯ ВОСТОЧНЫХ ФИННО-УГОРСКИХ ЯЗЫКОВ. МАТЕРИАЛЫ КОНФЕРЕНЦИИ, САРАНСК: КРАСНЫЙ ОКТЯБРЬ, С. 255-256 
KUDRIAVTSEVA \& SHABYKOV 2002 = Р. КУДРЯВЦЕВА, В. ШАБЫКОВ, РЕСПУБЛИКА МАРИЙ ЭЛ: ЯЗЫКОВАЯ СИТУАЦИЯ И ЯЗЫКОВАЯ ПОЛИТИКА В СФЕРЕ ОБРАЗОВАНИЯ. РУССКИЙ ЯЗЫК В ФОРМИРОВАНИИ МЕЖЭТНИЧЕСКОЙ СОЛИДАРНОСТИ (РЕГИОНАЛЬНЫЕ АСПЕКТЫ ЯЗЫКОВОЙ СИТУАЦИИ В РОССИИ И БЛИЖНЕМ ЗАРУБЕЖЬЕ), МОСКВА: ИЗД-ВО РУДН.

KUZMIN et al. 2005 = М. КУЗЬМИН, Д. НАСИЛОВ, О. АРТЕМЕНКО, «РОДНЫЕ ЯЗЫКИ КОРЕННЫХ МАЛОЧИСЛЕННЫХ НАРОДОВ СЕВЕРА В КОНТЕКСТЕ РЕФОРМИРОВАНИЯ СИСТЕМЫ ОБРАЗОВАНИЯ», КРУГЛЫЙ СТОЛ ПО ПРОБЛЕМАМ ЯЗЫКОВ КОРЕННЫХ НАРОДОВ СИБИРИ, НАХОДЯЩИХСЯ ПОД УГРОЗОЙ ИСЧЕЗНОВЕНИЯ, Г. МОСКВА, 27-28 ОКТЯБРЯ 2005 Г. МОСКВА: ИЭА РАН.

KUZMIN \& ARTEMENKO 2010 = М. КУЗЬМИН, О. АРТЕМЕНКО, «ЯЗЫКОВАЯ ПОЛИТИКА В РОССИИ В СВЕТЕ НОВЫХ ПРАВОВЫХ НОРМ», ЭТНОПОЛИТИЧЕСКАЯ СИТУАЦИЯ В РОССИИ И СОПРЕДЕЛЬНЫХ ГОСУДАРСТВАХ В 2009 ГОДУ. ЕЖЕГОДНЫЙ ДОКЛАД СЕТИ ЭТНОЛОГИЧЕСКОГО МОНИТОРИНГА И РАННЕГО ПРЕДУПРЕЖДЕНИЯ КОНФЛИКТОВ, ПОД РЕД. В. ТИШКОВА И В. СТЕПАНОВА, МОСКВА: ИЭА PAH, С. 44-46.

KUZMINA 2012 = Т. КУЗЬМИНА, «НАЦИОНАЛЬНОЕ ОБРАЗОВАНИЕ В МУНИЦИПАЛЬНЫХ ОБРАЗОВАТЕЛЬНЫХ УЧРЕЖДЕНИЯХ Г. ИЖЕВСКА», ИНФОРМАЦИОННЫЙ ВЕСТНИК УПРАВЛЕНИЯ ОБРАЗОВАНИЕМ АДМИНИСТРАЦИИ ГОРОДА ИЖЕВСКА, № 3, С. 8-10.

KYMLICKA Will, GrIN François, 2003, “Introduction - Assessing the Politics of Diversity in Transition Countries", in Nation-building, Ethnicity and Language Politics in Transition Countries, eds. F. Grin \& F. Daftar, Budapest: ECMI, pp. 1-29.

LALAIEVA 2005 = М. ЛАЛАЕВА, «МАНСИЙСКИЙ ЯЗЫК В СОЦИОКУЛЬТУРНОМ ПРОСТРАНСТВЕ ЮГРЫ», КРУГЛЫЙ СТОЛ ПО ПРОБЛЕМАМ ЯЗЫКОВ КОРЕННЫХ НАРОДОВ СИБИРИ, НАХОДЯЩИХСЯ ПОД УГРОЗОЙ ИСЧЕЗНОВЕНИЯ, Г. МОСКВА, 27-28 ОКТЯБРЯ 2005 Г. МОСКВА: ИЭА РАН.

LALLUKKa Seppo, 1990, The East Finnic Minorities in the Soviet Union: an appraisal of the erosive trends, Helsinki: Societas Scientiarum Fennica, 344 p.

LALLUKKA Seppo, 1994, "The Status of the Volga Finnic languages in the Soviet Comprehensive School", in Linguistic Studies in the non-Slavic languages of the CIS and the Baltic Republics, ed. H. I. Aronson, Chicago: University of Chicago, pp. 187-210.

LEONTIEv Alexei, 1995, "Linguistic Human Rights and Educational Policy in Russia", in Linguistic Human Rights, eds. T. Skutnabb-Kangas and R. Phillipson, Berlin-New York: Mouton de Gruyter, pp. 63-70.

LIKHANOVA Fenya, 2008, The Situation of Languages of Indigenous Small Numbered Peoples of the North, Siberia and the Far East, International Expert Group Meeting on Indigenous Languages held on 810 January 2008, New York: UN.

MARTYNENKO 2011a = А. МАРТЫНЕНКО, «РЕСПУБЛИКА МОРДОВИЯ: ФИННО-УГОРСКИЕ ЯЗЫКИ И РЕГИОНАЛЬНАЯ ПЕРСПЕКТИВА В СФЕРЕ ОБРАЗОВАНИЯ», ПРАВОВОЙ СТАТУС ФИННО-УГОРСКИХ ЯЗЫКОВ И ЭТНОКУЛЬТУРНЫЕ ПОТРЕБНОСТИ РОССИЙСКОЙ ШКОЛЫ, ПОД РЕД. В. А. ТИШКОВА, МОСКВА: ИП А. Г. ЯковЛЕВ, С. 178-188.

MARTYNENKO 2011b = А. МАРТЫНЕНКО, «РЕСПУБЛИКА МОРДОВИЯ: МОНИТОРИНГ ЭТНОКУЛЬТУРНЫХ ФОРМ ОБРАЗОВАНИЯ», ПРАВОВОЙ СТАТУС ФИННО-УГОРСКИХ ЯЗЫКОВ И ЭТНОКУЛЬТУРНЫЕ ПОТРЕБНОСТИ РОССИЙСКОЙ ШКОЛЫ, ПОД РЕД. В. А. ТИШКОВА, МОСКВА: ИП А. Г. ЯковлЕВ, С. 189-210.

Materials 2009 = «МАТЕРИАЛЫ, ПРЕДСТАВЛЕННЫЕ К ПАРЛАМЕНТСКИМ СЛУШАНИЯМ», О МЕРАХ ПО РЕАЛИЗАЦИИ ЦЕЛЕЙ ВТОРОГО МЕЖДУНАРОДНОГО ДЕСЯТИЛЕТИЯ КОРЕННЫХ НАРОДОВ МИРА В 
СФЕРАХ НАРОДНОГО ОБРАЗОВАНИЯ И СОХРАНЕНИЯ РОДНЫХ ЯЗЫКОВ В РАЙОНАХ ПРОЖИВАНИЯ КОРЕННЫХ МАЛОЧИСЛЕННЫХ НАРОДОВ СЕВЕРА, СИБИРИ И ДАЛЬНЕГО ВОСТОКА РОССИЙСКОЙ ФЕДЕРАЦИИ: ПАРЛАМЕНТСКИЕ СЛУШАНИЯ, 02 ОКТЯБРЯ 2008 Г., МОСКВА: ИЗД. СОВЕТА ФЕДЕРАЦИИ, С. 57-126.

MOSIN 2005 = М. МОСИН, «НАЦИОНАЛЬНОЕ САМОСОЗНАНИЕ МОРДОВСКОГО (МОКШАНСКОГО И ЭРЗЯНСКОГО) НАРОДА: НАСТОЯЩЕЕ И БУДУЩЕЕ», НАЦИОНАЛЬНОЕ САМОСОЗНАНИЕ МОРДОВСКОГО (МОКШАНСКОГО И ЭРЗЯНСКОГО) НАРОДА: НАСТОЯЩЕЕ И БУДУЩЕЕ, ДОКЛАДЫ НА IV СЪЕЗДЕ МОРДОВСКОГО (МОКШАНСКОГО И ЭРЗЯНСКОГО) НАРОДА, САРАНСК: КРАСНЫЙ ОКТЯБРЬ, С. 10-28. MOSIN 2006 = М. МОСИН, «СОСТОЯНИЕ ПРЕПОДАВАНИЯ ФИННО-УГОРСКИХ ЯЗЫКОВ В УСЛОВИЯХ НАЦИОНАЛЬНО-РУССКОГО ДВУЯЗЫЧИЯ В ФИННО-УГОРСКИХ РЕГИОНАХ РОССИЙСКОЙ ФЕДЕРАЦИИ», СОСТОЯНИЕ НАЦИОНАЛЬНО-РУССКОГО ДВУЯЗЫЧИЯ В ФИННО-УГОРСКИХ РЕГИОНАХ РОССИЙСКОЙ ФЕДЕРАЦИИ, МАТЕРИАЛЫ КОНФЕРЕНЦИИ. САРАНСК: КРАСНЫЙ ОКТЯБРЬ, С. 3-7.

MOSIN 2009 = М. МОСИН, МОРДОВСКИЕ ЯЗЫКИ: НАСТОЯЩЕЕ И БУДУЩЕЕ, СБОРНИК МАТЕРИАЛОВ И СТАТЕЙ, САРАНСК: МГУ ИМ. Н.П. ОГАРЕВА.

Obrazovanie 2005 = ОБРАЗОВАНИЕ ДЛЯ КОРЕННЫХ НАРОДОВ СИБИРИ: СОЦИОКУЛЬТУРНАЯ РОЛЬ НОВОСИБИРСКОГО ГОСУДАРСТВЕННОГО УНИВЕРСИТЕТА, ПОД РЕД. Н. ДИКАНСКОГО И ДР., НОВОСИБИРСК: НОНПАРЕЛЬ.

OSSIPOV \& SAPOZHNIKOV 2004 = А. ОСИПОВ, Р. САПОЖНИКОВ, «ЗАКОНОДАТЕЛЬСТВО РОССИЙСКОЙ ФЕДЕРАЦИИ, ИМЕЮЩЕЕ ОТНОШЕНИЕ К ЭТНИЧНОСТИ. КОНЦЕПТУАЛЬНЫЕ ОСНОВЫ, СОДЕРЖАНИЕ, ПРОБЛЕМЫ РЕАЛИЗАЦИИ», ПРОБЛЕМЫ ПРАВОВОГО РЕГУЛИРОВАНИЯ МЕЖЭТНИЧЕСКИХ ОТНОШЕНИЙ И АНТИДИСКРИМИНАЦИОННОГО ЗАКОНОДАТЕЛЬСТВА В РОССИЙСКОЙ ФЕДЕРАЦИИ, МОСКВА: НЕМЕЦКОРУсСКИЙ ОБМЕН, С. 162-208.

PASANEN Annika, 2003, Kielipesä ja revitalisaatio. Karjalaisten ja inarinsaamelaisten kielipesätoiminta, Pro gradu-tutkielma, Helsinki: Helsingin yliopisto, $134 \mathrm{p}$.

PODLESNYКН 2002 = О. ПОДЛЕСНЫХ, «РЕСПУБЛИКА МОРДОВИЯ: О СОСТОЯНИИ НАЦИОНАЛЬНОГО ОБРАЗОВАНИЯ», ЭТНОКОНФЕССИОНАЛЬНАЯ СИТУАЦИЯ В ПРИВОЛЖСКОМ ФЕДЕРАЛЬНОМ ОКРУГЕ. БЮЛЛЕТЕНЬ СЕТИ ЭТНОЛОГИЧЕСКОГО МОНИТОРИНГА И РАННЕГО ПРЕДУПРЕЖДЕНИЯ конФликтов, № 38.

POPOV \& NESTEROVA 2000 = А. ПОПОВ, Н. НЕСТЕРОВА, НАЦИОНАЛЬНЫЙ ВОПРОС В РЕСПУБЛИКЕ КОМИ В КОНЦЕ ХХ ВЕКА (ИСТОРИЧЕСКОЕ ИССЛЕДОВАНИЕ), СЫКТЫВКАР: КОМИ НЦ УРО РАН. PoPOV 2010 = Ю. ПОПОВ, «КОМИ ДЕТИ ТЕРЯЮТ РОДНОЙ ЯЗЫК, ИЗУЧАЯ ЕГО КАК «ГОСУДАРСТВЕННЫЙ», ИНФОРМАЦИОННОЕ АГЕНТСТВО Finnougr.ru, 12 МАЯ 2010 ГОДА. Pravovoi status 2011 = ПРАВОВОЙ СТАТУС ФИННО-УГОРСКИХ ЯЗЫКОВ И ЭТНОКУЛЬТУРНЫЕ ПОТРЕБНОСТИ РОССИЙСКОЙ ШКОЛЫ, ПОД РЕД. В. А. ТИШКОВА, МОСКВА: ИП А. Г. ЯКОВЛЕВ. RAKНMATULLINA 2006 = 3. РАХМАТУЛЛИНА, «О ЗАДАЧАХ ПО ИЗУЧЕНИЮ ГОСУДАРСТВЕННЫХ И РОДНЫХ ЯЗЫКОВ В ОБРАЗОВАТЕЛЬНЫХ УЧРЕЖДЕНИЯХ», ПЕДАГОГИЧЕСКИЙ ЖУРНАЛ БАШКОРТОСТАНА, № 2 (3), С. 5-14.

Russian Federation: The Human Rights Situation of the Mari Minority of the Republic of Mari El. A Study of the Titular Nationality of One of Russia's Ethnic Regions, Joint Report of the International Helsinki Federation for Human Rights and the Moscow Helsinki Group, Vienna: IHF, $2006,56 \mathrm{p}$. 
SADOVSKII $2000=$ Н. САДОВСКИЙ, «КОМИ ЯЗЫК В СИСТЕМЕ ОБРАЗОВАНИЯ», РАЗВИТИЕ КОМИ ЯЗЫКА НА СОВРЕМЕННОМ ЭТАПЕ: ПРОБЛЕМЫ И ПЕРСПЕКТИВЫ, МАТЕРИАЛЫ КОНФЕРЕНЦИИ, ПОД РЕД. А. СМЕТАНИНА И ДР., СЫКТЫВКАР: КОМИ НЦ УРО РАН, С. 22-28.

SAFIN $1994=$ Ф. САФИН, «ЯЗЫКОВОЙ АСПЕКТ СУВЕРЕНИЗАЦИИ В БАШКОРТОСТАНЕ», ОТЕЧЕСТВЕННАЯ ИСТОРИЯ, № 4-5, С. 161-168.

SAFIN 1997 = Ф. САФИН, «КОНФЛИКТОГЕННЫЙ ПОТЕНЦИАЛ ПОСТСОВЕТСКОЙ НАЦИОНАЛЬНОЙ ПОЛИТИКА В БАШКОРТОСТАНЕ В СФЕРЕ ОБРАЗОВАНИЯ», РЕСУРСЫ МОБИЛИЗОВАННОЙ ЭТНИЧНОСТИ, ПОД РЕД. М. ГУБОГЛО И ДР., МОСКВА-УФА: ИЭА РАН, С. 191-222.

SAGITOVA 2011= Л. САГИТОВА. «МОТИВАЦИЯ К ИЗУЧЕНИЮ ЯЗЫКОВ СРЕДИ УЧАЩИХСЯ ШКОЛ РТ И ИХ РОДИТЕЛЕЙ», ЯЗЫКИ В СИСТЕМЕ ОБРАЗОВАНИЯ РЕСПУБЛИКИ ТАТАРСТАН: ПО МАТЕРИАЛАМ ЭТНОСОЦИОЛОГИЧЕСКОГО ИССЛЕДОВАНИЯ, ПОД РЕД. Р. МУСИНОЙ И ДР., КАЗАНЬ: ТАТАРСКОЕ КНИЖНОЕ ИЗДАТЕЛЬСТВО.

SAlo Merja, 2005, “The Status of Mordvinian and Mari in School Curriculum”, in Mari und Mordwinen im heutigen Rußland. Sprache, Kultur, Identität, eds. E. Helimski, U. Kahrs und M. Schätschel, Wiesbaden: Harrassowitz Verlag, pp. 97-118.

SAVELYEVA Eleonora, 2000, "Venäjän suomalais-ugrilaisten kansojen kielilainsäädännöstä ja kansallisista kouluista", in Sukukansapäivien satoa. Kirjoituksia ja puheenvuoroja suomalaisugrilaisuudesta, Marja Lappalainen (ed.), Castrenianumin toimitteita 57. Helsinki: Castren Society, pp. 86-96.

SHABAEV et al. 2009 = Ю. ШАБАЕВ, В. ДЕНИСЕНКО И Н. ШИЛОВ, «ЯЗЫКОВАЯ ПОЛИТИКА В РЕГИОНАХ ПРОЖИВАНИЯ ФИННО-УГОРСКИХ НАРОДОВ РОССИЙСКОЙ ФЕДЕРАЦИИ: ПОИСК МОДЕЛИ», РЕГИОНОЛОГИЯ, № 2, С. 296-309.

SHAROV 2002 = В. ШАРОВ, «РЕСПУБЛИКА МАРИЙ ЭЛ: ЭТНОЯЗЫКОВАЯ СИТУАЦИЯ», ЭТНОКОНФЕССИОНАЛЬНАЯ СИТУАЦИЯ В ПРИВОЛЖСКОМ ФЕДЕРАЛЬНОМ ОКРУГЕ. БЮЛЛЕТЕНЬ СЕТИ ЭТНОЛОГИЧЕСКОГО МОНИТОРИНГА И РАННЕГО ПРЕДУПРЕЖДЕНИЯ КОНФЛИКТОВ, № 40.

SHAROV 2010 = В. ШАРОВ, «ШКОЛА - ИСТОЧНИК ЯЗЫКА», ЭТНОКУЛЬТУРНОЕ ОБРАЗОВАНИЕ. МЕТОДЫ СОЦИАЛЬНОЙ ОРИЕНТАЦИИ РОССИЙСКОЙ ШКОЛЫ, РЕД. В. СТЕПАНОВ, ВЫП. 1, МОСКВА: ИЭА РАН, С. 5660.

SHILOV $2002=$ Н. ШИЛОВ, «РЕСПУБЛИКА МОРДОВИЯ: О СОСТОЯНИИ НАЦИОНАЛЬНОГО ОБРАЗОВАНИЯ», ЭТНОКОНФЕССИОНАЛЬНАЯ СИТУАЦИЯ В ПРИВОЛЖСКОМ ФЕДЕРАЛЬНОМ ОКРУГЕ. БЮЛЛЕТЕНЬ СЕТИ ЭТНОЛОГИЧЕСКОГО МОНИТОРИНГА И РАННЕГО ПРЕДУПРЕЖДЕНИЯ конфликтов, № 38.

SHILOV $2004=$ Н. ШИЛОВ, «РЕСПУБЛИКА МОРДОВИЯ: МОРДОВСКИЙ ЯЗЫКА СТАЛИ ОБЯЗАТЕЛЬНЫМИ В ОБЩЕОБРАЗОВАТЕЛЬНЫХ ШКОЛАХ», ЭТНОКОНФЕССИОНАЛЬНАЯ СИТУАЦИЯ В ПРИВОЛЖСКОМ ФЕДЕРАЛЬНОМ ОКРУГЕ. БЮЛЛЕТЕНЬ СЕТИ ЭТНОЛОГИЧЕСКОГО МОНИТОРИНГА И РАННЕГО ПРЕДУПРЕЖДЕНИЯ КОНФЛИКТОВ, № 86.

SHUTOV 2003 = А. ШУТОВ, «ИЗУЧЕНИЕ ВОСТОЧНЫХ ФИННО-УГОРСКИХ ЯЗЫКОВ В СИСТЕМЕ ОБРАЗОВАНИЯ РОССИЙСКОЙ ФЕДЕРАЦИИ», ПРОБЛЕМЫ И ПЕРСПЕКТИВЫ РАЗВИТИЯ ВОСТОЧНЫХ ФИННОУГОРСКИХ ЯЗЫКОВ. МАТЕРИАЛЫ КОНФЕРЕНЦИИ, САРАНСК: КРАСНЫЙ ОКТЯБРЬ, С. 16-21.

SPODINA 2011 = В. СПОДИНА, «ХАНТЫ-МАНСИЙСКИЙ АВТОНОМНЫЙ ОКРУГ: ЭТНИЧЕСКИЕ ЯЗЫКИ В ВУЗАХ И ШКОЛАХ РЕГИОНА», ПРАВОВОЙ СТАТУС ФИННО-УГОРСКИХ ЯЗЫКОВ И ЭТНОКУЛЬТУРНЫЕ ПОТРЕБНОСТИ РОССИЙСКОЙ ШКОЛЫ, ПОД РЕД. В. А. ТИШКОВА, МОСКВА: ИП А. Г. ЯКОВЛЕВ, С. 211-239. 
STEPANOV 2011 = В. СТЕПАНОВ, «О МЕТОДАХ ОЦЕНКИ ЯЗЫКОВЫХ И ЭТНОКУЛЬТУРНЫХ ПОТРЕБНОСТЕЙ В СИСТЕМЕ ШКОЛЬНОГО ОБРАЗОВАНИЯ», ПРАВОВОЙ СТАТУС ФИННО-УГОРСКИХ ЯЗЫКОВ И ЭТНОКУЛЬТУРНЫЕ ПОТРЕБНОСТИ РОССИЙСКОЙ ШКОЛЫ, ПОД РЕД. В. А. ТИШКОВА, МОСКВА: ИП А. Г. ЯКОВЛЕВ, С. 247-269.

STROGALSHCHIKOVA 2006 = 3. СТРОГАЛЬЩИКОВА, «РОДНОЙ ЯЗЫК: ПРАВО И РЕАЛЬНОСТЬ», МНОГООБРАЗИЕ ЯЗЫКОВ НАРОДОВ РОССИИ - НАЦИОНАЛЬНОЕ ДОСТОЯНИЕ И КУЛЬТУРНОЕ БОГАТСТВО НАШЕЙ СТРАНЫ, ПЕТРОЗАВОДСК: ПЕРИОДИКА, С. 5-34.

STROGALSHCHIKOVA 2008 = 3. СТРОГАЛЬЩИКОВА, «ФИННО-УГОРСКИЕ ЯЗЫКИ: СОВРЕМЕННОЕ СОСТОЯНИЕ, ИСПОЛЬЗОВАНИЕ В СИСТЕМЕ ОБРАЗОВАНИЯ», ФИННО-УГОРСКИЕ НАРОДЫ РОССИИ: ВЧЕРА, СЕГОДНЯ, ЗАВТРА, СЫКТЫВКАР: КОМИ ВОЙТЫР, С. 140-154.

TAAGEPERA Rein, 1999, The Finno-Ugric Republics and the Russian State, London: Hurst and Company, $449 \mathrm{p}$.

Territoriia 2010 = «ТЕРРИТОРИЯ ЛЮБВИ: ОБУЧЕНИЕ ДЕТЕЙ КОРЕННЫХ НАРОДОВ ЯМАЛА», УЧИТЕЛЬСКАЯ ГАЗЕТА - РЕГИОН ЯМАЛО-НЕНЕЦКИЙ АВТОНОМНЫЙ ОКРУГ, 30 НОЯБРЯ 2010 ГОДА.

TISHKOV Valerii, STEPANOV Valerii, FUNK Dmitri and ARTEMENKO Olga (eds.), 2009, Status of and Support for Linguistic Diversity in the Russian Federation, Expert Report, Moscow: IEA RAS, 75 p.

TSYPANOV 2001 = Е. ЦЫПАНОВ, «КОМИ ЯЗЫК: ПУТЬ К ГОСУДАРСТВЕННОМУ», РЕСПУБЛИКЕ КОМИ 80 ЛЕТ. ОЧЕРКИ, ПОСВЯЩЕННЫЕ 80-ЛЕТИЮ ГОСУДАРСТВЕННОСТИ РЕСПУБЛИКИ КОМИ В СОСТАВЕ РОССИЙСКОЙ ФЕДЕРАЦИИ, СЫКТЫВКАР: КОМИ НЦ УРО РАН, С. 174-196.

Tverskie vedomosti 2010 = ТВЕРСКИЕ ВЕДОМОСТИ, № 50, 17-23 ДЕКАБРЯ.

VASILIEVA $2008=$ Г. ВАСИЛЬЕВА, «ЦЕННОСТНЫЕ ОРИЕНТАЦИИ УЧАЩИХСЯ В КОНТЕКСТЕ НАЦИОНАЛЬНОГО ОБРАЗОВАНИЯ В УДМУРТСКОЙ РЕСПУБЛИКЕ», ОБРАЗОВАНИЕ И НАУКА. ИЗВЕСТИЯ УРО РАН, № 2 (50), С. 98-104.

VASILIEVA $2010=$ Н. ВАСИЛЬЕВА, «РАЗВИТИЕ СИСТЕМЫ ОБУЧЕНИЯ ФИНСКОМУ ЯЗЫКУ В РЕСПУБЛИКЕ КАРЕЛИЯ», РОССИЙСКИЕ ФИННЫ: ВЧЕРА, СЕГОДНЯ, ЗАВТРА, ПОД РЕД. Е. КЛЕМЕНТЬЕВА, ПЕТРОЗАВОДСК: КАРЕЛЬСКИЙ НЦ РАН, С. 168-173.

VASILIEVA \& VORONTSOV $2008=$ Г. ВАСИЛЬЕВА, В. ВОРОНЦОВ, «ЭТНОЯЗЫКОВЫЕ ПРОЦЕССЫ И ЯЗЫКОВАЯ ПОЛИТИКА В УДМУРТИИ», ЯЗЫКОВОЕ И ЭТНИЧЕСКОЕ ВОЗРОЖДЕНИЕ В УДМУРТИИ: ОТ ПОЛИТИКИ К КУЛЬТУРНОМУ МНОГООБРАЗИЮ. КОЛЛЕКТИВНАЯ МОНОГРАФИЯ, ПОД РЕД. К. УИЛЛЬЯМСА И ДР., ИЖЕВСК: УДГУ, С. 20-73.

VORONTSOV 2006 = В. ВОРОНЦОВ, «ЭТНОКУЛЬТУРНЫЕ АСПЕКТЫ ОБРАЗОВАНИЯ», ЭТНОКОНФЕССИОНАЛЬНАЯ СИТУАЦИЯ В ПРИВОЛЖСКОМ ФЕДЕРАЛЬНОМ ОКРУГЕ. БЮЛЛЕТЕНЬ СЕТИ ЭТНОЛОГИЧЕСКОГО МОНИТОРИНГА И РАННЕГО ПРЕДУПРЕЖДЕНИЯ КОНФЛИКТОВ, № 116.

VORONTSOV 2009 = В. ВОРОНЦОВ, «ОПЫТ РЕАЛИЗАЦИИ ЯЗЫКОВОЙ ПОЛИТИКИ В УДМУРТИИ», ФИННО-УГРЫ - СЛАВЯНЕ - ТЮРКИ: ОПЫТ ВЗАИМОДЕЙСТВИЯ (ТРАДИЦИИ И ИННОВАЦИИ), МАТЕРИАЛЫ КОНФЕРЕНЦИИ, ИЖЕВСК: УДГУ, С. 656-667.

VORONTSOV \& SEMENOV 2010 = В. ВОРОНЦОВ, Ю. СЕМЕНОВ, «АКТИВНАЯ ПОЗИЦИЯ РОДИТЕЛЕЙ И ШКОЛЫ», ЭТНОКУЛЬТУРНОЕ ОБРАЗОВАНИЕ. МЕТОДЫ СОЦИАЛЬНОЙ ОРИЕНТАЦИИ РОССИЙСКОЙ ШКОЛЫ. РЕД. В. СТЕПАНОВ. ВЫП. 1. МОСКВА: ИЭА РАН, С. 108-126.

ZAMYATIN Konstantin, 2012, "The Education Reform in Russia and Its Impact on Teaching of the Minority Languages: an Effect of Nation-Building?", Journal on Ethnopolitics and Minority Issues in Europe, 11 (1), pp. 17-47. 
ZAMYATIN Konstantin, 2012, "From Language Revival to Language Removal? The Teaching of Titular Languages in the National Republics of Post-Soviet Russia", Journal on Ethnopolitics and Minority Issues in Europe, 11 (2), pp. 75-102.

ZAMYATIN Konstantin, 2013, "Sovereignisation and State Languages: Early Formation of Language Policy of Russia's Finno-Ugric Republics in the Conditions of the USSR Disintegration", FinnischUgrische Mitteilungen, 36, pp. 1-42.

\section{NOTES}

1. In Russian: ИНСТИТУТЫ ПОВЫШЕНИЯ КВАЛИФИКАЦИИ УЧИТЕЛЕЙ.

2. In Russian: МАЛОКОМПЛЕКТНЫЕ ШКОЛЫ.

\section{ABSTRACTS}

After the collapse of the USSR, not only the former union republics, but also autonomous republics and regions inside post-Soviet Russia adopted extensions of native-language teaching in school as one of the central goals of their national revival and language revival policy. To achieve this goal, regional authorities adopted legislation and created an institutional framework for language education. Depending on the resultant configuration of the legal-institutional framework of language education, the dynamics in implementing the goal of language teaching extension in regions varied. How have different regional configurations of the legal-institutional framework affected language teaching? This study explores the position of Finno-Ugric languages in Russian regional education systems using a legal-institutional approach. The effect of the policy is studied by employing calculation of the dynamics in the relative share of native language learners in school. The empirical study demonstrates that the frameworks of teaching the native languages in Finno-Ugric republics and autonomous districts are comparable, but that access to native language learning was provided to differing degrees.

Après l'écroulement de l'URSS, les anciennes républiques de l'Union, mais aussi les républiques autonomes et certaines régions au sein de la Russie post-soviétique étendirent l'enseignement de la langue maternelle dans les écoles et en firent l'un des principaux objectifs de la revitalisation nationale et de la politique de revitalisation des langues. Pour réaliser cet objectif, les autorités régionales adoptèrent des lois et donnèrent à l'enseignement des langues un cadre juridique. Suivant la configuration de ce dernier, la dynamique dans la mise en œuvre de l'enseignement des langues vernaculaires a pu différer selon les régions. Comment les différentes configurations régionales du cadre institutionnel et juridique ont-elles influé sur l'enseignement de la langue? Cet article étudie la position des langues finno-ougriennes dans les systèmes régionaux d'éducation de la Russie sur la base d'une approche juridique. Les effets de ladite politique sont étudiés sur la base de la dynamique dans la part relative des apprenants de leur langue maternelle à l'école. Il révèle que les cadres d'enseignement des langues autochtones dans les régions et républiques finno-ougriennes sont comparables, mais qu'ils permettent l'accès aux langues vernaculaires à des degrés divers. 


\section{INDEX}

Mots-clés: langues finno-ougriennes, langues finno-ougriennes, langues minoritaires, langues minorées, éducation dans les langues minorées, cadre juridique et institutionnel

Geographical index: Bachkortostan (République), Républiques turcophones, Tatarstan (République), Mari-El (République), Komi (République), Mordovie (République), Oudmourtie (République), Carélie (République), Iamalo-Nénétsie (Yamalie) (district autonome), KhantyMansiïsk (Ougrie) (district autonome), Kirov (oblast'), Saint-Pétersbourg, Murmansk, NižniNovgorod, Tver, Krasnoïarsk, Perm, Sakha (Iakoutie) (République), Touva (République),

Tchétchénie (République), Adygué (République)

Keywords: finno-Ugric languages, minority language education, legal-institutional framework, Russian Federation 